\title{
Análise estrutural do Metagranito Capané, Complexo Porongos, Cachoeira do Sul, RS
}

\author{
Gustavo ZVIRTES ${ }^{1}$, Ruy Paulo PHILIPP², Eduardo CAMOZZATO ${ }^{1,3}$ \& Felipe GUADAGNIN ${ }^{4}$
}

1 Programa de Pós-graduação em Geociências, Instituto de Geociências, Universidade Federal do Rio Grande do Sul. Av. Bento Gonçalves, 9.500, CEP 91.540-000, Porto Alegre, RS, Brasil (zvirtes@yahoo.com.br).

2 Centro de Estudos em Petrologia e Geoquímica, Instituto de Geociências, Universidade Federal do Rio Grande do Sul. Av. Bento Gonçalves, 9.500, CEP 91.540-000, Porto Alegre, RS, Brasil (ruy.philipp@ufrgs.br).

3 Universidade do Vale do Rio dos Sinos. Av.Unisinos, 950, CEP 93.022-750, São Leopoldo, RS, Brasil (eduardo.camozzato@gmail.com).

4 Universidade Federal do Pampa, Campus Caçapava do Sul. Av. Pedro Anunciação 111, CEP 96.570-000, Caçapava do Sul, RS, Brasil (felipe.guada@yahoo.com.br).

Recebido em 06/2016. Aceito para publicação em 12/2016.

Versão online publicada em 08/05/2017 (www.pesquisasemgeociencias.ufrgs.br)

\begin{abstract}
Resumo - A análise estrutural e as relações de contato entre o Metagranito Capané (MC) e as rochas metavulcanosedimentares neoproterozoicas do Complexo Porongos (CP) são discutidas a partir da integração entre o mapeamento geológico de detalhe e análise microtectônica. A área de estudo está situada na região centro-sul do estado de Rio Grande do Sul, na Antiforme Capané, estrutura regional com caimento para SW. As unidades do CP foram intensamente deformadas e metamorfisadas durante a etapa final da formação do Cinturão Dom Feliciano, entre 600 e 570 Ma. 0 Metagranito Capané, posicionado no flanco oeste da antiforme é um aegirina pertita granito milonítico com textura equigranular hipidiomórfica média localmente preservada e foliação milonítica (Sm) bem desenvolvida. 0 corpo apresenta forma alongada e concordante com a foliação $S_{2}$ dos xistos pelíticos e das rochas metavulcânicas encaixantes. A Sm possui direção NNE e mergulha em média $30^{\circ}$ para WNW, e a lineação de estiramento (Lx) tem baixo ângulo de caimento $\left(<10^{\circ}\right)$ para SSW. As microestruturas observadas são típicas de milonitos de grau médio, condição equivalente às encaixantes metassedimentares. Os indicadores cinemáticos, como pares SC e a assimetria de porfiroclastos deformados, indicam transporte tectônico de topo para SSW com cinemática sinistral. Essa milonitização está associada à geração de zonas de cisalhamento oblíquas de direção NE-SW durante o período pós-colisional de formação do Cinturão Dom Feliciano.

Palavras-chave: Cinturão Dom Feliciano, Antiforme Capané, Metagranito, Zona de Cisalhamento Dúctil, Microtectônica.
\end{abstract}

\begin{abstract}
Structural Analysis of Capané Metagranite, Porongos Complex, Cachoeira do Sul, RS. The structural analysis and the contact relationships between the Capané Metagranite (CM) and the Neoproterozoic metavocanosedimentary rocks of Porongos Complex (PC) is discussed based on detailed geological mapping integrated with microtectonic analysis. The study area is located in the south central region of the state of Rio Grande do Sul, in the Capané Antiform, a regional structure dipping to SW. These units were intensively deformed and metamorphosed during the post-collisional phase of the Dom Feliciano Belt at the end of the Brasiliano Cycle (600-560 Ma). The Capané Metagranite, positioned on the west flank of the antiform is a milonitic aegirine pertite granite with locally preserved medium equigranular hipydiomorphic texture and well developed milonitic foliation (Sm). The body presents an elongated shape and agrees with the $\mathrm{S}_{2}$ foliation of the pelitic schists and the metavolcanic rocks. The Sm has NNE direction and plunges on average $30^{\circ}$ to WNW, and the stretch lineation (Lx) has a low angle dip $\left(<10^{\circ}\right)$ to SSW. The microstructures observed are typical of medium grade mylonites, equivalent to the condition of metasedimentary host rocks. The kinematic indicators as SC pairs and asymmetric porphyroclasts suggest top-to S-SW sense of movement. The mylonitization is linked to the activation of NE-oriented oblique shear zones during compressional deformation related to the final stages of the evolution of Dom Feliciano Belt.
\end{abstract}

Keywords: Dom Feliciano Belt, Capané Antiform, Metagranite, Ductile Shear Zone, Microtectonic. 


\section{Introdução}

A análise tectônica de rochas metamórficas envolve o estudo das associações litológicas, suas configurações geométricas, dinâmicas e cinemáticas, integrando o levantamento de dados desde a escala de cinturões orogênicos até estruturas e texturas microscópicas. No caso de cinturões orogênicos, os processos deformacionais são geralmente acompanhados por metamorfismo, modificando parcialmente a mineralogia, as texturas e estruturas da rocha. As mudanças nas condições físicas e químicas ocorrem em resposta a dinâmicas geológicas de grande escala, relacionadas à movimentação de placas tectônicas que afetam as rochas crustais e mantélicas (Bucher \& Grapes, 2011).

O Complexo Porongos (CP), localizado na porção centro-sul do Estado do Rio Grande do Sul, é uma das principais unidades do Terreno Tijucas. Definido primeiramente como Suíte Metamórfica Porongos por Jost (1981), registra uma sucessão metassedimentar, incluindo quartzitos, xistos pelíticos, mármores e rochas calci-silicáticas, intercalada com rochas metavulcânicas compostas por metadacitos, metariolitos e meta-andesitos. As unidades do CP recobrem o embasamento granito-gnáissico do Complexo Encantadas, de idade paleoproterozoica (2,2 -2,0 Ga) (Soliani Jr., 1986; Hartmann et al., 2003; Philipp et al., 2008). O CP foi submetido a metamorfismo regional orogênico que varia da fácies xisto verde inferior a anfibolito superior, resultado das movimentações tectônicas convergentes entre os crátons Rio de La Plata e Kalahari durante a fase final de evolução do Ciclo Brasiliano (Jost \& Bitencourt, 1980).

Embora pouco estudados, foram identificados vários corpos graníticos intrusivos no Complexo Porongos (Camozzato \& Marques 1977; Marques et al., 1998a, 1998b; Orlandi $\mathrm{F}^{\circ}$ et al., 2000; Camozzato et al., 2012). Os granitos possuem formas tabulares com centenas de metros de comprimento e espessuras que chegam a dezenas de metros. Estes granitos ocorrem como corpos alongados deformados por uma foliação milonítica concordante com a foliação das rochas metamórficas encaixantes. Os granitos podem ser divididos em dois grupos: (i) granitos peraluminosos, com muscovita, turmalina e granada e (ii) granitos alcalinos a peralcalinos, com Fe-biotita e piroxênio alcalino, respectivamente.

Este artigo apresenta a análise estrutural do aegirina pertita granito milonítico, denominado por Zvirtes et al. (2013) de Metagranito Capané (MC) e suas rochas encaixantes metassedimenta- res através de mapeamento litoestrutural e análise microtectônica. Os objetivos principais são (i) caracterizar a mineralogia e as condições de cristalização; (ii) definir as condições de posicionamento e de deformação na crosta (grau metamórfico e fases de deformação); (iii) determinar os mecanismos deformacionais atuantes e definir as possíveis tensões e condições cinemáticas envolvidas. Este estudo caracteriza os eventos ígneos e metamórficos no Complexo Porongos na porção sul da Antiforme Capané.

\section{2 Área, materiais e métodos}

\subsection{Contexto geológico regional}

Localizado na porção meridional da Província Mantiqueira (Almeida et al., 1971), o Terreno Tijucas compõe a unidade central do Cinturão Dom Feliciano. Esta região constituiu a parte sudoeste do Supercontinente Gondwana, o qual foi composto por blocos cratônicos arqueanos e paleoproterozoicos cercados por cinturões orogênicos neoproterozoicos gerados no ciclo Brasiliano/Pan-Africano (Fig. 1).

o Escudo Sul-Riograndense (ESRG) é o resultado do processo de geração e deformação de crosta continental e da porção superior do manto, cujas maiores contribuições são registradas em dois ciclos orogênicos (i) Ciclo Transamazônico (2.37 - 2,00 Ga) e (ii) Ciclo Brasiliano/Pan-Africano (900-540 Ma) (Fig. 2) (Chemale Jr. et al., 1995; Fernandes et al., 1995; Chemale Jr., 2000; Hartmann et al., 2007).

O ESRG é dividido em duas grandes unidades geotectônicas de acordo com suas características estruturais, geofísicas, petrológicas e geocronológicas: (1) 0 Cráton Rio de La Plata (CRLP), representado como um fragmento de idade paleoproterozoica e núcleos arqueanos; e, (2) o Cinturão Dom Feliciano (CDF), uma faixa orogênica de idade neoproterozoica orientada segundo a direção NE-SW, construída na porção oriental do CRLP durante o Ciclo Brasiliano (Fragoso Cesar, 1980). No RS o CDF é constituído pelo Terreno São Gabriel (TSG), Terreno Tijucas (TTj), Batólito Pelotas (BP) e pela Bacia do Camaquã (Figura 2).

O TSG é constituído pela intercalação tectônica de unidades metavulcânicas e metagraníticas de caráter juvenil e associações ofiolíticas, representando a abertura e o fechamento do Oceano Charrua, com a criação de um arco de ilhas oceânico (Arco Passinho), e um arco continental (Arco São Gabriel), acrescionados na borda ocidental do Ter- 
reno Nico Perez (Babinski et al., 1996; Saalmann et al., 2005; Hartmann et al., 2011). 0 TTj constitui uma bacia vulcanossedimentar metamorfisada representada pelo Complexo Porongos, depositada em ambiente de margem passiva e de back-arc sobre um embasamento granito-gnáissico paleoproterozoico, representado pelo Complexo Encantadas (Philipp et al., 2008). Estas unidades foram deformadas e metamorfisadas em sucessivas fases compressionais compondo uma série de dobramentos e cavalgamentos durante o final do Ciclo Brasiliano. O BP é o cenário de reciclagem crustal com fusão parcial de sequências metamórficas paleo- e neoproterozoicas e múltiplas intrusões graníticas brasilianas, geradas através da atuação zonas de cisalhamento dúcteis durante o período sin a pós-colisional do CDF (Philipp \& Machado, 2005; Philipp et al., 2007).

As unidades do embasamento foram formadas pela interação entre placas a partir do início do Paleoproterozoico, com metamorfismo regional granulítico entre 2,02 e 2,10 Ga com acresção juvenil no Terreno Taquarembó (Mantovani et al., 1987; Hartmann, 1988), e durante o Neoproterozoico com o Ciclo Brasiliano/Pan Africano que re- trabalhou a borda leste do Cráton Rio de La Plata, durante a aglutinação do Gondwana, gerando o Cinturão Dom Feliciano (Chemale Jr., 2000; Hartmann et al., 2007; Basei et al., 2008; figs. 1 e 2).

\subsection{Relações estratigráficas do Complexo Porongos}

A área de estudo está localizada na porção norte do Complexo Porongos no Cinturão Dom Feliciano, um cinturão orogênico neoproterozoico gerado a partir de episódios acrescionários, colisionais e pós-colisionais (transcorrentes e extensionais) durante a construção da porção SW do Gondwana, entre os períodos Toniano e Ediacarano (Babinski et al., 1996; Saalmann et al., 2005; Hartmann et al., 2011; Philipp et al., 2013) (Fig. 1).

o Complexo Porongos (CP), inserido no Terreno Tijucas, compreende uma associação de rochas metavulcanossedimentares, metamorfisadas em condições de grau baixo a médio, entre as fácies xisto verde inferior e anfibolito superior (Jost \& Bitencourt, 1980; Camozzato et al., 2012). Encontra-se disposto como uma faixa alongada de direção N30E, com $170 \mathrm{~km}$ de comprimento e 15

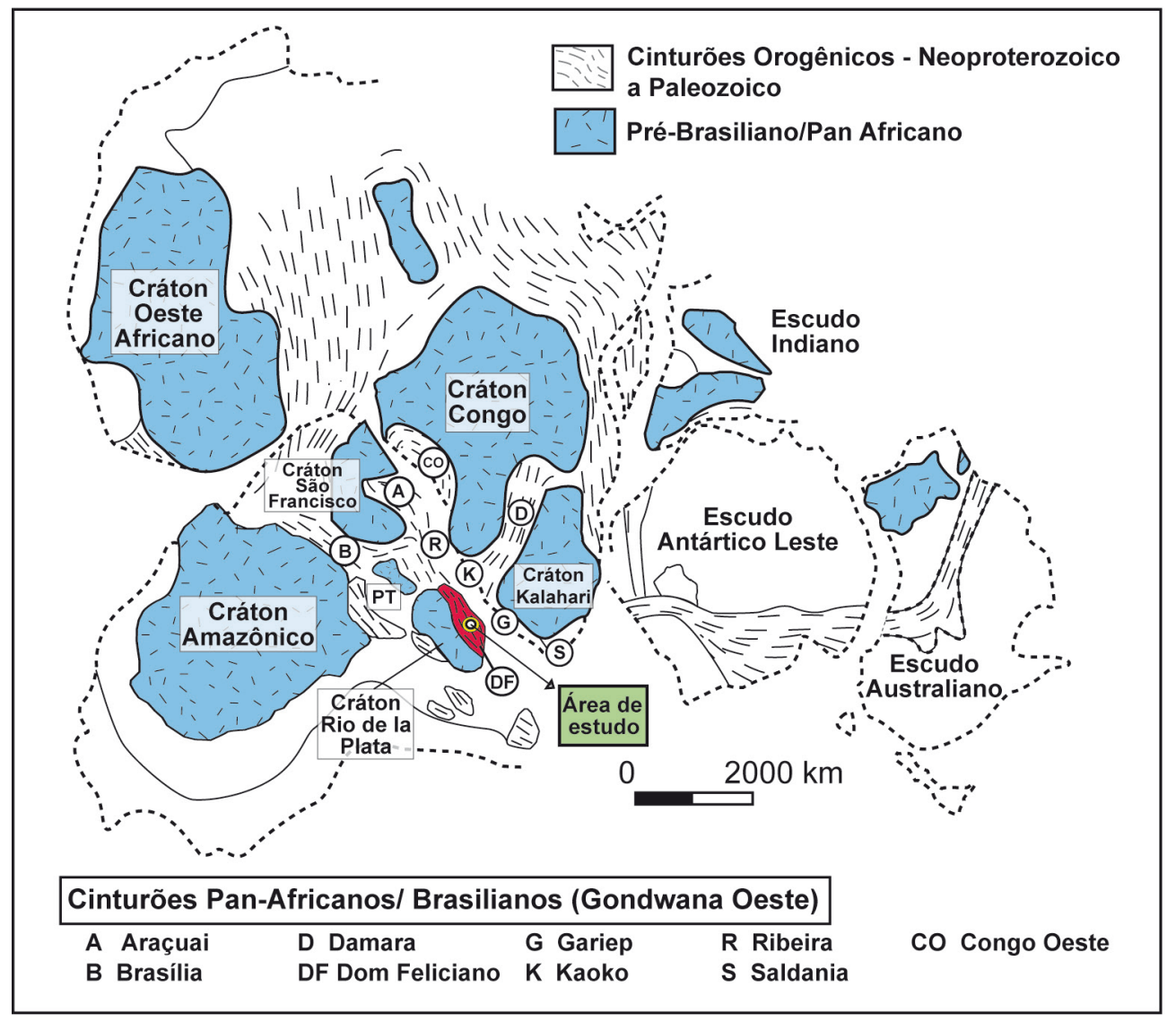

Figura 1. Configuração tectônica do setor oeste do Gondwana com as principais áreas cratônicas (em azul) e cinturões orogênicos (linhas tracejadas); o Cinturão Dom Feliciano é realçado em vermelho com a localização da área de estudo (modificado de Saalmann et al., 2005).

Figure 1.Tectonic configuration of the West Gondwana showing the main cratonic areas (blue) and orogenic belts (dash lines); the Dom Feliciano Belt is highlighted in red with the location of the studied area (modified from Saalmann et al., 2005). 


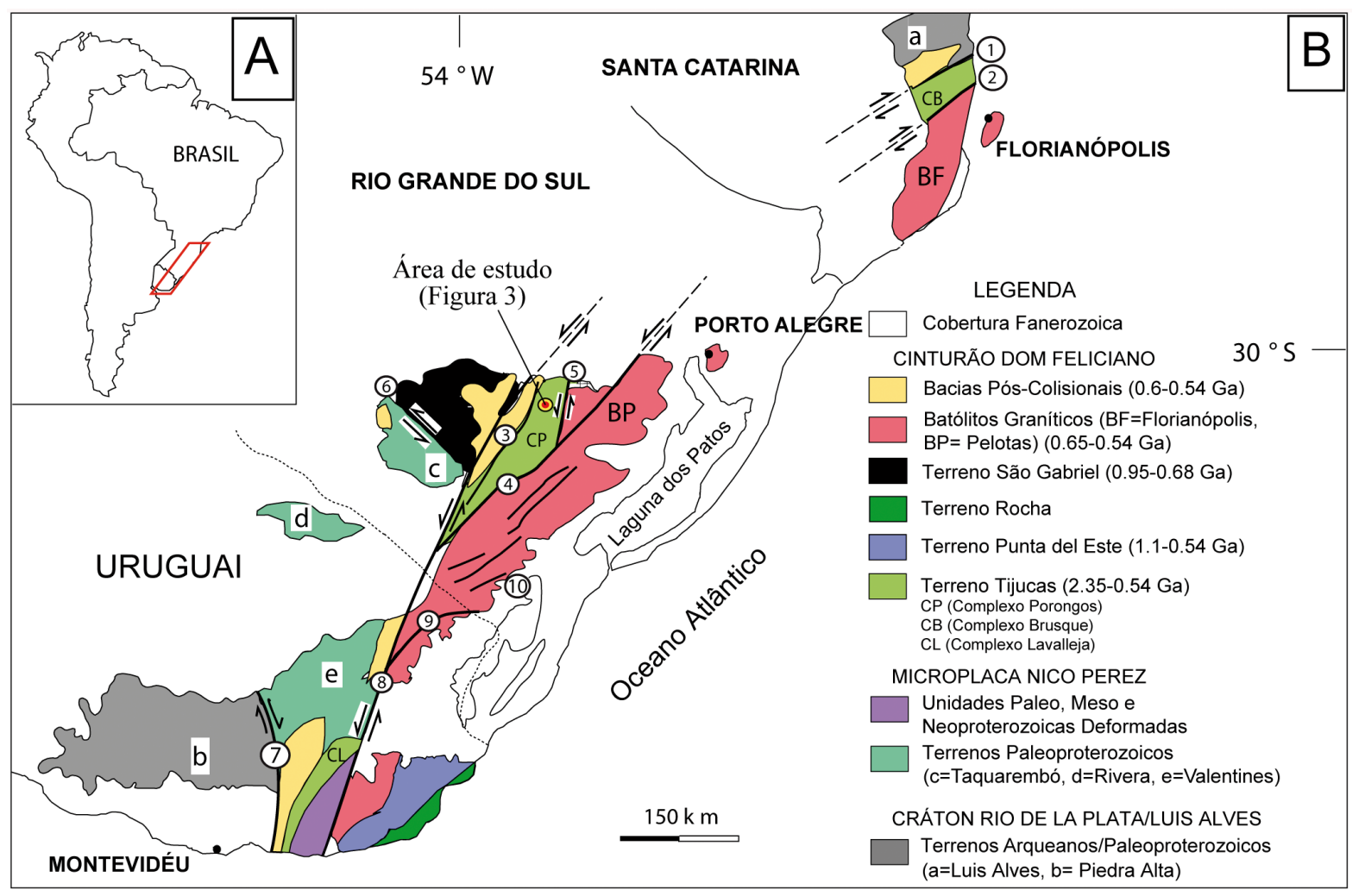

Figura 2. Mapa geotectônico e de localização. A) Localização dos escudos Sul-Brasileiros e Uruguaio na América do Sul; B) Principais unidades geotectônicas do sul do Brasil e Uruguai. Zonas de cisalhamento: 1- Itajaí-Perimbó; 2- Major Gercino; 3- Santana da Boa Vista; 4- Dorsal do Canguçu; 5- Passo do Marinheiro; 6- Ibaré; 7- Sarandi Del Y; 8- Sierra Ballena; 9- Cerro Amaro; 10 Arroio Grande (modificado de Philipp et al., 2013).

Figure 2. Geotectonic and location maps. A) Location of the South Brazilian and Uruguayan Shields in South America; B) Main geotectonic units of Brazil and Uruguay. Shear Zones: 1- Itajaí-Perimbó;, 2- Major Gercino; 3- Santana da Boa Vista; 4- Dorsal do Canguçu; 5- Passo do Marinheiro; 6- Ibaré; 7- Sarandi Del Y; 8- Sierra Ballena; 9- Cerro Amaro, 10-Arroio Grande (modified from Philipp et al., 2013).

a $30 \mathrm{~km}$ de largura (Fig. 3). 0 CP está limitado ao leste com o Batólito Pelotas pelas Zonas de Cisalhamento Dorsal de Canguçu (ZCDC) e Passo do Marinheiro (ZCPM). Apresenta contatos tectônicos através da Zona de Cisalhamento de Caçapava do Sul (ZCCS), a Oeste, com recobrimento parcial pelas rochas sedimentares da Bacia do Camaquã. Ao Norte está recoberto pelas rochas fanerozoicas da Bacia do Paraná (Chemale Jr., 2000).

0 Complexo Porongos é composto por metapelitos, xistos carbonosos, quartzitos, mármores e lentes de metamargas. As rochas metavulcânicas são metariolitos, metadacitos e metandesitos, ocorrendo intercaladas com os metassedimentos e registrando as mesmas condições metamórficas (Jost \& Bitencourt, 1980; Marques et al., 1998a, 1998b; Gollmann et al., 2008; Camozzato et al., 2012). Muitos ambientes foram propostos para a bacia do Porongos, incluindo margem passiva (Jost \& Bitencourt, 1980), margem ativa (Chemale Jr., 2000) e bacia de retro-arco (Fernandes et al., 1995; Hartmann et al., 2007; Philipp et al., 2013).

Os dados isotópicos e de elementos-traço das rochas metavulcânicas e dos metassedimentos indicam um retrabalhamento do embasamento
pré-Brasiliano, sugerindo a deposição em crosta continental distendida ou em um arco magmático continental, com retrabalhamento de crosta continental paleoproterozoica (Hartmann et al., 2007). Dados geocronológicos de U-Pb em zircões detríticos dos metassedimentos do CP mostram três fontes principais com idades paleo-, meso- e neoproterozoica (Hartmann et al., 2003; Gruber et al., 2011; Pertille et al., 2015), sugerindo uma evolução a partir de uma margem passiva para uma bacia de retro-arco (Jost \& Bitencourt, 1980) ou de foreland (Pertille et al., 2015).

Análises $\mathrm{U}-\mathrm{Pb}, \mathrm{Lu}-\mathrm{Hf}$ e de isótopos de oxigênio obtidos em zircões detríticos do CP por Pertille et al. (2015) ressaltaram a existência de duas associações distintas de metassedimentos neste complexo. Os metassedimentos da região de Santana da Boa Vista apresentam uma composição química compatível com sedimentos de margem passiva com proveniência paleo a mesoproterozoica, enquanto os metassedimentos da região de Capané possuem uma composição geoquímica compatível com rochas fontes relacionada com arcos magmáticos e com proveniência detrítica dominantemente neoproterozoica. 


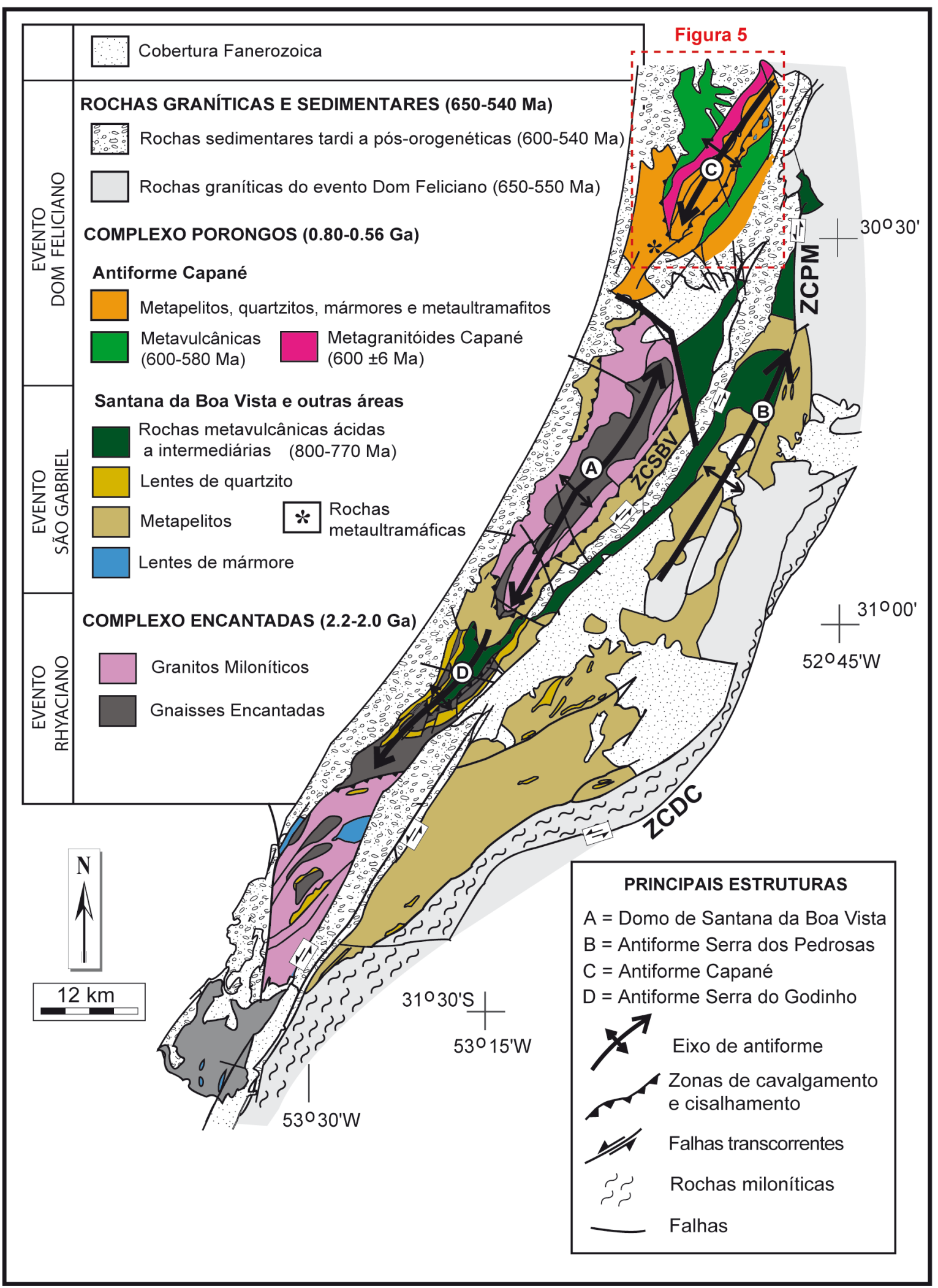

Figura 3. Mapa geológico do Complexo Porongos. Zonas de cisalhamento: ZCDC = Zona de Cisalhamento Dorsal de Canguçu; ZCSBV = Zona de Cisalhamento Santana da Boa Vista; ZCPM = Zona de Cisalhamento Passo do Marinheiro.

Figure 3. Geological map of Porongos Complex. Shear zones: ZCDC = Zona de Cisalhamento Dorsal de Canguçu; ZCSBV = Zona de Cisalhamento Santana da Boa Vista; ZCPM = Zona de Cisalhamento Passo do Marinheiro. 
A presença de corpos graníticos intrusivos ao longo do Complexo Porongos foi registrada por diversos pesquisadores (Chemale Jr., 2000; Orlandi Fo. et al., 2000; Philipp \& Camozzato, 2009; Camozzato et al., 2012). Dentre estes corpos destacam-se o Metagranito Capané, da Antiforme Capané (Fig. 3) e os granitos alcalinos miloníticos da região de Hulha Negra e Candiota (Metagranito Candiotinha) (Camozzato et al., 2012). Esta última unidade é representada por um pertita granito peralcalino que apresentou idade U-Pb em zircão de $589 \pm 25$ Ma (Camozzato et al., 2013).

\subsection{Arcabouço estrutural do CP}

A estruturação do CP está definida por quatro principais estruturas antiformais de escala quilométrica (Fig. 3), denominadas Domo de Santana da Boa Vista, Antiforme Serra dos Pedrosas, Antiforme Capané e Antiforme Serra do Godinho (Jost \& Bitencourt, 1980).

O Domo de Santana da Boa Vista é uma estrutura alongada segundo direção $\mathrm{N} 45^{\circ} \mathrm{E}$, cujo núcleo e infraestrutura expõem o embasamento paleoproterozoico representado pelos Gnaisses Encantadas e por metagranitoides associados, e uma supraestrutura composta por metapelitos, quartzitos e mármores neoproterozoicos. Seus eixos caem em baixo ângulo para SW e NE materializando uma braquiantiforme. A Antiforme Serra dos Pedrosas, situada a nordeste do Domo de Santana da Boa Vista, consiste principalmente de rochas metavulcânicas intermediárias à ácidas e subordinadamente composta por metapelitos e xistos grafitosos (Jost \& Bitencourt, 1980; Jost, 1981); possui direção N20ํㅡ com eixo caindo em baixo ângulo para NE. A Antiforme Serra do Godinho apresenta a mesma direção $\mathrm{N} 20^{\circ} \mathrm{E}$ com eixo caindo suavemente para SW; ocorre ao sul do Rio Camaquã e expõe as rochas supracrustais neoproterozoicas do CP e o embasamento paleoproterozoico do Complexo Encantadas. No extremo norte do CP ocorre a Antiforme Capané(AC), a qual corresponde à área de estudo do presente trabalho. $\mathrm{A}$ AC é composta por rochas metavulcânicas máficas e félsicas, rochas metassedimentares como pelitos, quartzitos e mármores e granitóides miloníticos. 0 eixo desta antiforme possui caimento de aproximadamente $20^{\circ}$ para $\mathrm{SW}$.

O CP apresenta uma trama estrutural complexa caracterizada por quatro fases de dobramentos e pelo desenvolvimento de duas foliações metamórficas principais (Jost \& Bitencourt, 1980; Remus et al., 1987., 1990). A foliação metamórfica principal $\mathrm{S}_{2}$ contém dobras $\mathrm{F}_{2}$ intrafoliais com for- mas apertadas e isoclinais, em escala de $1-10 \mathrm{~cm}$, caracterizadas por relictos da foliação metamórfica $\mathrm{S}_{1}$, gerada com o primeiro episódio de deformação $\mathrm{D}_{1}$ (Fig. 4A).

O dobramento e a transposição da xistosidade $S_{1}$ marcam o desenvolvimento da clivagen de crenulação e xistosidade $S_{2}$ na segunda fase de deformação $\left(\mathrm{D}_{2}\right)$. Durante o desenvolvimento das foliações $S_{1}$ e $S_{2}$ foram atingidas condições metamórficas entre a fácies xisto verde inferior e anfibolito médio (Jost, 1981). A foliação $S_{2}$ exibe uma lineação mineral e de estiramento com direção NNE-SSW. A presença de feições microestruturais como quartzo estirado e mica fish nos metassedimentos atestam a atuação de zonas de cisalhamento dúcteis durante o desenvolvimento da foliação $\mathrm{S}_{2}$. Indicadores cinemáticos sugerem um sentido aparente de cisalhamento de topo para NNE (Remus et al., 1990; Fernandes et al., 1992).

A fase de deformação $\mathrm{D}_{3}$ está marcada pelo redobramento das dobras $\mathrm{F}_{2}$ e pela geração das dobras $\left(\mathrm{F}_{3}\right)$, que possuem formas abertas a fechadas e amplitude regional, e com eixos caindo para NE e SW (Fig. 4B). Essa fase é responsável pela estruturação do relevo do CP através de estruturas antiformais de escala quilométrica, como a Antiforme Capané, onde o MC está posicionado em seu flanco oeste.

A terceira e a quarta fase de deformação $\left(D_{3}\right.$ e $\mathrm{D}_{4}$ ) ocorreram em condições retrogressivas de caráter rúptil-dúctil e rúptil, respectivamente, estando representadas por clivagens de fratura $\mathrm{CS}_{3}$ e $\mathrm{S}_{4}$ ) de direção predominantemente NE-SW e NW-SE (Fig. 4C). Segundo Jost \& Bitencourt (1980) e Jost (1981) as primeiras fases de dobramentos foram associadas com falhas de empurrão com vergência para NW. Estas estruturas, do tipo nappes, foram responsáveis pelo espessamento crustal, e também pelo transporte tectônico para NW das unidades situadas na porção sudeste do Complexo Porongos, posicionando-as sobre as unidades situadas a noroeste.

A pilha de fatias de empurrão, segundo estes mesmos autores, relacionadas às fases $\mathrm{D}_{1}$ e $\mathrm{D}_{2}$, foi dobrada e recortada por falhas dúctil-rúpteis a rúpteis em regime de cisalhamento transcorrente sinistral. De acordo com Chemale Jr. (2000), bacias de pull-apart, delimitadas por falhas, formaram-se em segmentos transtracionais, com formas estreitas e alongadas, segundo a direção NE-SW (e.g. Sub-bacia do Piquiri), que poderiam estar relacionadas cronologicamente com a fase de deformação $\mathrm{D}_{3}$ e com as dobras $\mathrm{F}_{3}$. Estas bacias representam os primeiros depósitos da Bacia do Camaquã. Esta sequência também foi afetada por falhamentos re- 


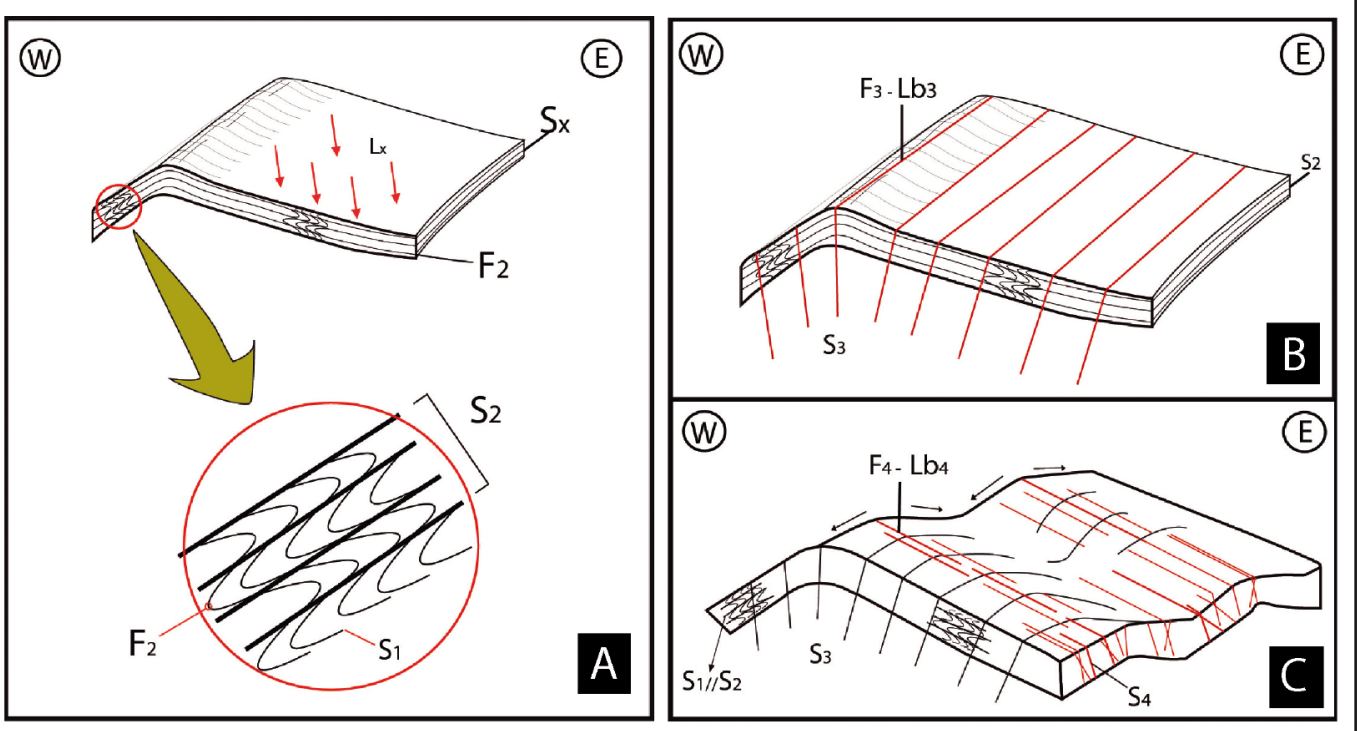

Figura 4. Modelos esquemáticos representando as diferentes fases de deformação e estruturas identificadas em campo no Complexo Porongos. A) Detalhe da foliação metamórfica $S_{1}$ como dobras intrafoliais $\left(F_{2}\right)$ gerando a foliação metamórfica $S_{2}$; $)$ Dobramento da foliação $S_{2}$ em estrutura antiformal de escala regional, gerando clivagem de fratura $\left(S_{3}\right)$ nos planos axiais com direção NE; C) Representação da fase deformacional de caráter mais rúptil, com clivagens de fraturas subverticais $\left(\mathrm{S}_{4}\right)$ segundo SE-NW, afetando as estruturas pré-existentes.

Figure 4. Schematic models showing the different deformational phases and structures identified in the Porongos Complex. A) Detail of the metamorphic foliation $S_{1}$ with intrafolial folds $\left(F_{2}\right)$ generating the metamorphic foliation $\left.S_{2} ; B\right) F_{3}$ fold deforming the $S_{2}$ foliation in a large scale antiformal structure, with $S_{3}$ spaced cleavage along the NE-oriented axial plane; C) Representation of brittle deformational phase with SE-NW-striking sub-vertical spaced cleavage $\left(S_{4}\right)$, afecting the previous structures.

lacionados a eventos deformacionais mais jovens, como a fase de deformação $\mathrm{D}_{4}$.

\subsection{Materiais e Métodos}

A análise estrutural do MC foi realizada através de (1) integração do mapeamento geológico do metagranito e de suas encaixantes, com coleta de dados estruturais de foliações, lineações, dobras e fraturas; (2) análise geométrica da forma e das atitudes das estruturas na busca de associações estruturais para descrever diferentes sistemas deformacionais; (3) análise deformacional e cinemática, especialmente integradas à análise microtectônica; (4) análise dinâmica com ênfase no reconhecimento das principais fases de deformação e respectivas tensões regionais que afetaram as unidades; e (5) interpretação e integração destes dados para a contribuição da análise tectônica do Cinturão Dom Feliciano no Complexo Porongos.

Os dados estruturais foram tratados estatisticamente e ilustrados a partir de diagramas estereográficos, os quais foram comparados para definir as fases de deformação correspondentes entre as distintas litologias. Para classificação petrológica e avaliação dos diferentes tipos e graus de deformação reconhecidos durante os trabalhos de campo, foram selecionadas quinze amostras representativas para confecção de lâminas petrográficas, sendo sete orientadas. As lâminas delgadas foram confeccionadas no Laboratório de Preparação de Amostras do Instituto de Geociências da UFRGS. As amostras orientadas foram serradas de acordo com a seção X-Z do elipsóide de deformação para avaliar os indicadores cinemáticos de direção e sentido do transporte tectônico.

A análise petrográfica permitiu o reconhecimento da mineralogia primária e metamórfica, bem como avaliar a variação da intensidade da deformação a partir das texturas e microestruturas identificadas. A elaboração de croquis esquemáticos dos afloramentos foi crucial na organização e ilustração da geometria das estruturas mapeadas. Os resultados obtidos da análise estrutural e da petrografia foram comparados com outros dados disponíveis na literatura.

\section{Resultados e Discussões}

O Metagranito Capané é um aegirina pertita granito milonitizado, localizado no flanco oeste da Antiforme Capané. 0 corpo granítico possui forma alongada lenticular segundo a direção $\mathrm{N} 20^{\circ} \mathrm{E}$, com largura entre 300 e $600 \mathrm{~m}$ e comprimento de 4 $\mathrm{km}$, intrusivo em rochas metavulcano-sedimentares do Complexo Porongos. Aflora como lajeados e matacões nas porções mais altas da topografia, bordejado pelo Arroio Capané a oeste (Fig. 5). 
Os primeiros estudos no MC foram realizados por Camozzato \& Marques (1977) e Hartmann \& Jost (1980), onde o metagranito foi interpretado como um meta-arcóseo. No trabalho de Marques et al. (1998b), essas rochas foram denominadas de Gnaisses Capané e interpretadas como de origem ígnea, cujo magmatismo foi associado a evento extensional anterior ou concomitante à formação da Bacia do Porongos (Marques et al., 1998a).

Zvirtes et al. (2013) definem a idade de cristalização do MC de 603 \pm 6 Ma a partir de análises $\mathrm{U}-\mathrm{Pb}$ em zircão, com idade de metamorfismo de $539 \pm 9$ Ma, obtida a partir de bordas metamórficas de zircão e de cristais de titanita. Estes autores também definiram as características geoquímicas do MC como granitos alcalinos com características peralcalinas e interpretam o posicionamento do MC relacionado a magmatismo alcalino pós-colisional do Cinturão Dom Feliciano.

\subsection{Relações estratigráficas e estruturais}

A Antiforme Capané é composta essencialmente por rochas metavulcanossedimentares de fácies xisto verde inferior a anfibolito. A estrutura antiformal apresenta cerca de $20 \mathrm{~km}$ de comprimento e $12 \mathrm{~km}$ de largura, com eixo de caimento médio de $20^{\circ}$ para S40W (Fig. 5). 0 flanco oeste da antiforme mergulha em média $38^{\circ}$ para NW e o flanco leste mostra um mergulho médio de $30^{\circ} \mathrm{SE}$, caracterizando a dobra como do tipo normal com caimento.

Jost (1981) e Marques et al. (1998b) reconheceram duas grandes unidades litológicas, uma dominada por rochas metavulcânicas e outra por rochas metassedimentares. A unidade metavulcânica aflora principalmente ao longo do flanco oeste da Antiforme Capané, enquanto a unidade metassedimentar está concentrada nas porções central e leste desta megaestrutura. Estas unidades estão orientadas preferencialmente segundo NE-SW e foram intrudidas por corpos de granitóides leucocráticos, dentre eles o Metagranito Capané, hoje milonitizados e estirados em lentes kilométricas dispostas segundo a foliação metamórfica das encaixantes (Fig. 5).

A unidade metavulcânica foi subdividida em duas subunidades, uma félsica de afinidade cálcico-alcalina e outra intermediária à máfica de caráter transicional a toleí́tico. Segundo Marques et al. (1998a), esse vulcanismo se desenvolveu, em parte, associado a condições subaquosas e vulcanismo explosivo relacionado à subducção de crosta oceânica sob um continente durante o Neoproterozoico. $O$ conteúdo elevado de ETR e LILE e as relações de campo sugerem vulcanismo também associado à subducção de crosta oceânica sob um continente pré-existente, provavelmente representado pelas rochas granito-gnáissicas paleoproterozoicas do Complexo Encantadas.

As rochas metassedimentares consistem de metapelitos e quartzitos, com algumas lentes de mármores e xistos calci-silicáticos e, mais raramente, metaconglomerados. Os metapelitos e quartzitos são dominantes, enquanto os mármores se associam em sucessivas cristas e lentes no flanco leste com ótima exposição em antigas cavas de pedreiras. A natureza das rochas metassedimentares sugere sedimentação em ambiente de mar raso, com vulcanismo subaquoso (Jost, 1981; Marques et al., 1998b). Rochas metaultramáficas ocorrem como um alinhamento de lentes situadas ao longo do flanco oeste da antiforme. São compostas por serpentinitos com e sem textura reliquiar e, em menor quantidade, talco xistos, antofilita xistos e clorititos (Jost \& Bitencourt, 1980; Marques et al., 2003).

O MC é um aegirina pertita granito com textura porfiroclástica, marcada por porções protomiloníticas, miloníticas e ultramiloníticas ao longo do corpo (Fig. 6). A foliação milonítica (Sm) é definida por bandamento fino (1-3 mm), contínuo e regular, marcado pela alternância de níveis ricos em porfiroclastos de até $5 \mathrm{~mm}$ de K-feldspato pertítico e clinopiroxênio sódico, e níveis ricos em uma matriz de composição quartzo-feldspática com textura granoblástica inequigranular interlobada fina $(0,2$ $\mathrm{mm})$. Está orientada segundo a direção N20트, variando até $\mathrm{N} 20^{\circ} \mathrm{W}$, com mergulhos em média $40^{\circ}$ para WNW, com lineação de estiramento caindo de cerca de $10^{\circ}$ para $S 30^{\circ} \mathrm{W}$.

\subsection{Petrografia e Microestruturas}

As amostras do MC apresentam uma ampla variação na intensidade da deformação ao longo do corpo, resultando em grande variação do tamanho de grão e da proporção de porfiroclastos em relação a matriz, incluindo termos miloníticos a ultramiloníticos. Classificado como um aegirina pertita granito, o MC é composto por pertita (35$40 \%)$, quartzo (30-35\%), piroxênio (aegirina) (7-12\%), anfibólio (riebeckita) (0-3\%), titanita (1-3\%) e minerais opacos (3-5\%). Os termos miloníticos mostram uma pronunciada lineação de estiramento do quartzo e dos porfiroclastos de Kfeldspato e piroxênio com caudas de deformação assimétricas indicando transporte tectônico de topo para NE (Fig. 7B).

Os cristais de pertita, com até $8 \mathrm{~mm}$ de diâ- 


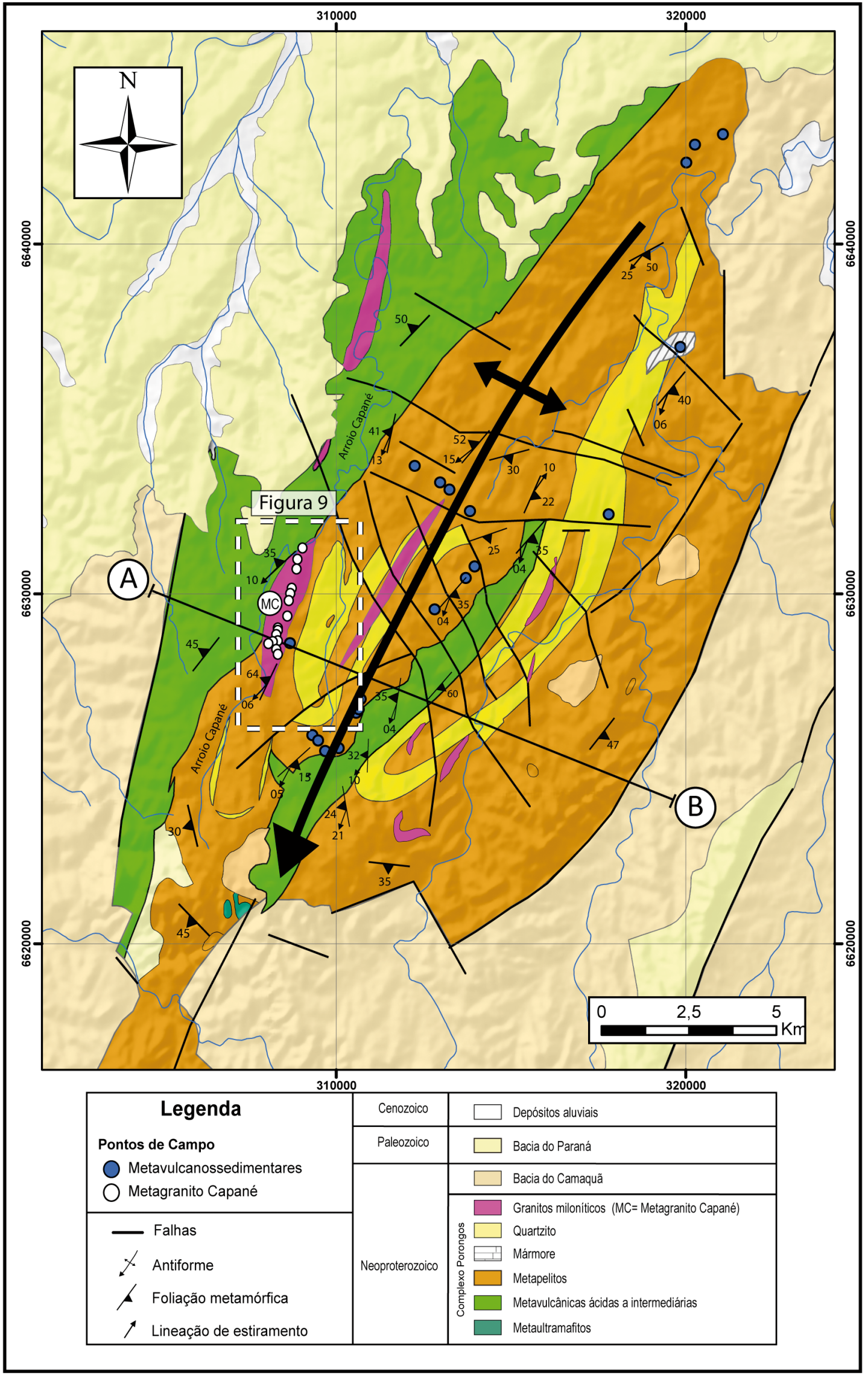

Figura 5. Mapa geológico da Antiforme Capané. Retângulo tracejado indica a localização do Metagranito Capané (MC) e da figura 9.

Figure 5. Geological map of Capané Antiform. Dashed rectangle indicates the location of Capané Metagranite (MC) and figure 9.. 

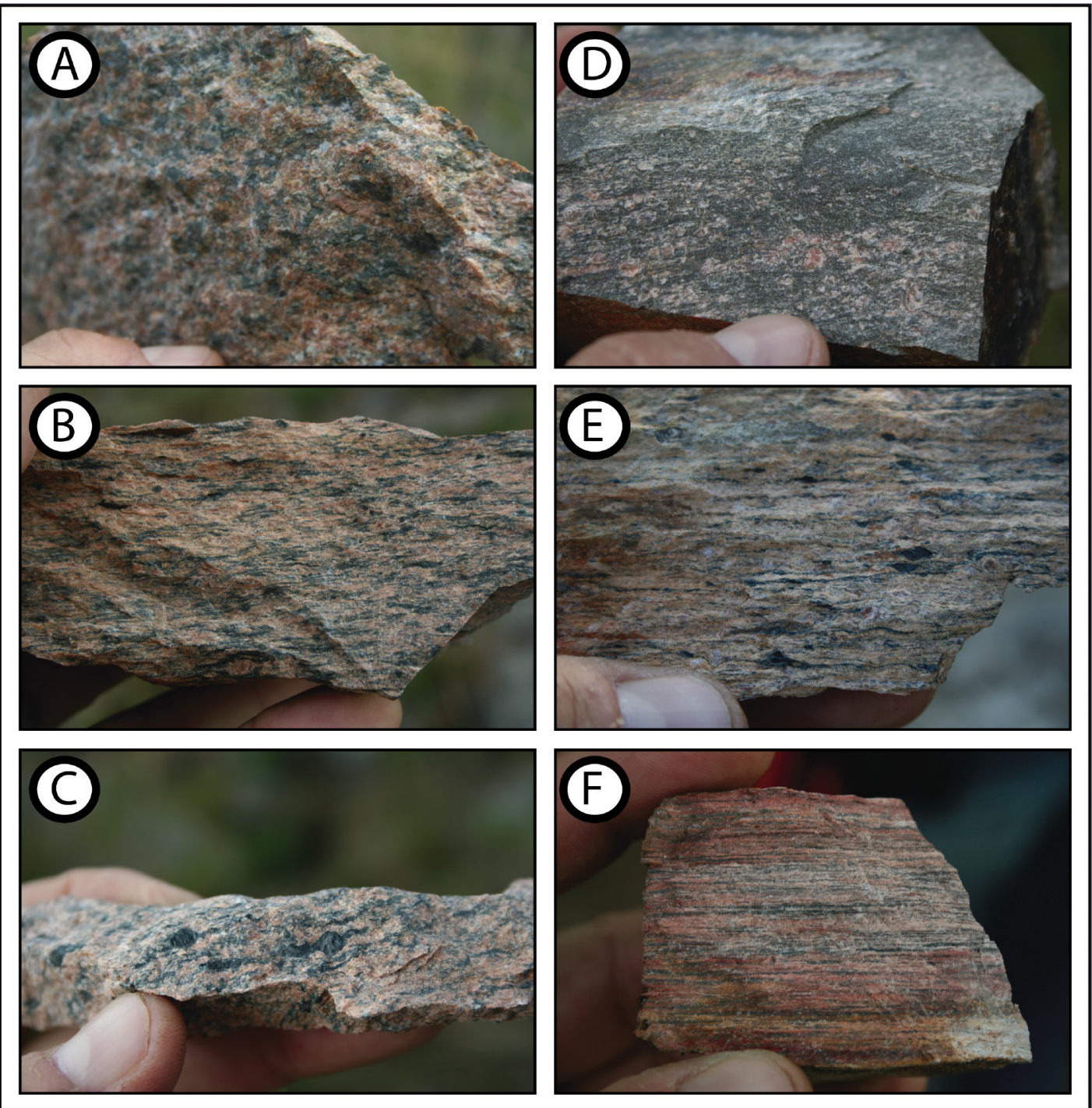

Figura 6. Variação textural macroscópica do MC com aumento da deformação de A para F. A) Pertita granito pouco deformado com textura equigranular média; B) Protomilonito com porfiroclastos de aegirina e pertita estirados; C) Milonito com porfiroclasto de aegirina com caudas de deformação assimétricas; D) Milonito com porfiroclastos de Kf de até 0,5 mm; E) Milonito com bandamento fino definido por níveis de minerais máficos descontínuos, com quartzos estirados e porfiroclastos de aegirina assimétricos; F) Ultramilonito com bandamento fino e contínuo de espessura milimétrica, composto por níveis de quartzo, K-feldspato e com minerais máficos estirados.

Figure 6. Macroscopic textural variation of MC with deformation increasing from A to F. A) Low strain pertite granite with medium equigranular texture; B) Protomylonite with stretched aegirine and pertite porfiroclasts; $C$ ) Mylonite with aegirine porfiroclasts with asymmetric deformational tails; D) Mylonite with Kf porfiroclasts with up to $0.5 \mathrm{~mm}$; E) Fine banding mylonite defined by discontinuous mafic levels and streched quartz and asymmetric aegirine porfiroclasts; F) Ultramilonite with thin and continuous banding of milimeter thickness, composed of levels of quartz, K-feldspar and stretched mafic minerlas.

metro, apresentam maclas Carlsbad e em grade. Essas maclas, especialmente nas porções protomiloníticas, estão quebradas ou levemente dobradas devido à deformação intracristalina (Fig. 7A). Em alguns destes cristais ocorre formação de coroa externa de albita. Os porfiroclastos estão amplamente recristalizados, principalmente, em suas bordas por processos de recristalização por rotação de subgrãos, gerando feições de tipo porfiroclastos manteados (mantled porfiroclasts) (Fig. 7 A, 7C e 7D).

Os porfiroclastos de piroxênio contêm forma prismática alongada, são subédricos, com tamanhos entre 1 e $4 \mathrm{~mm}$, com pleocroísmo variando de esverdeado a marrom amarelado (Fig. 7E, 7F, $8 \mathrm{~A}$ e 8B). Os porfiroclastos estão estirados segundo a foliação milonítica por processos de cominuição, muitas vezes gerando caudas de deformação assimétricas (Fig. 7B). Nos termos ultramiloníticos os porfiroclastos de feldspato e piroxênio são reduzidos em quantidade e tamanho, chegando, no máximo a $1 \mathrm{~mm}$ de diâmetro (Fig. 8C e 8D).

A matriz tem granulação fina à média $(0,05$ a $0,2 \mathrm{~mm}$ ) e apresenta textura granoblástica inequigranular à equigranular interlobada, resultante da intensa recristalização dos cristais de quartzo e feldspato. 0 quartzo ocorre essencialmente na matriz, estirado em forma de fitas (ribbons) ou asso- 
ciado ao feldspato na matriz (Fig.7A). Os diminutos cristais de pertita que ocorrem na matriz, também apresentam macla Carlsbad e em grade como fragmentos não recristalizados. Estes cristais possuem forma equidimensional com contatos retos a curvilíneos. 0 piroxênio (aegirina) presente na matriz ocorre como restos de grãos cominuídos pela deformação dos antigos porfiroclastos. 0 anfibólio (riebekita), de cor azul marinho e hábito acicular; está orientado e marca textura nematoblástica na forma de franjas finas ao redor dos minerais de aegirina, como uma fase de substituição por hidratação (Fig. 7E, 7F, 8A e 8B). Dados composicionais obtidos por Hartmann \& Jost (1980) por meio de microssonda eletrônica atestam que o piroxênio é uma aegirina-augita e o anfibólio é uma riebeckita.

Na matriz, os níveis milimétricos com ampla recristalização de quartzo e de feldspato mostram textura granoblástica poligonal com fino material oxidado entre os contatos. Ocorrem também bandas de até $1 \mathrm{~mm}$ de quartzo em forma de fitas com contatos serrilhados, circundando os porfiroclastos e marcando a foliação milonítica (Fig. 7A e 8C e 8D). Bandas monominerálicas de quartzo possuem até $2 \mathrm{~mm}$ de espessura e uma foliação oblíqua marcada pela orientação de maior eixo dos cristais de quartzo recristalizados gerando o plano $\mathrm{S}$ da deformação por cisalhamento simples em relação ao plano da foliação principal C (Fig. 8 C,D e F).

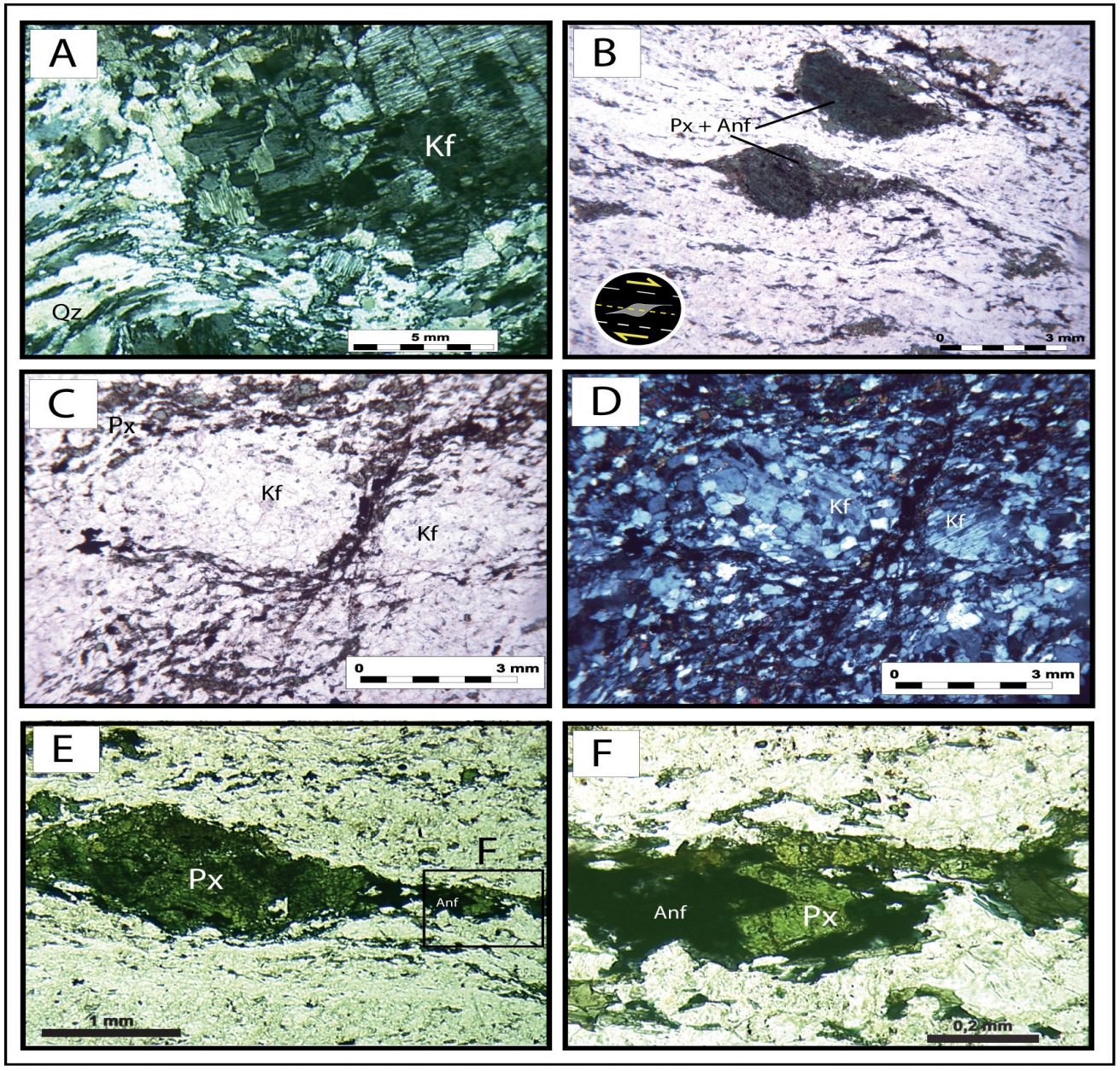

Figura 7. Fotomicrografias do MC. A) Protomilonito com porfiroclasto de pertita com intenso fraturamento gerando subgrãos com pouca recristalização nas bordas, envoltos por níveis de quartzo estirados em forma de fitas; B) Milonito com porfiroclastos do tipo sigma de aegirina estirados pela deformação gerando caudas assimétricas e estruturas do tipo "stair steeping"; C e D) Milonito com porfiroclastos de pertita envoltos por franja de novos cristais metamórficos gerando textura granoblástica poligonal do tipo núcleo e manto (mantled porfiroclast); E) Milonito com porfiroclastos de aegirina cominuidos pela milonitização envoltos por franjas de anfibólio (riebeckita) de cor azul escuro; F) Detalhe da figura 7E - Porfiroclastos de aegirina envoltos por anfibólios. Abreviações dos minerais: Px- Piroxênio (Aegirina); Anf- Anfibólio; Kf- K feldspar (Pertita).

Figure 7. Photomicrographs of MC. A) Protomilonite with porphyroclasts of pertite with intense fracturing developing sub-grains with subordinate recristalization on borders, surrounded by quartz ribbons ; B) Mylonite with stretched aegirine porfiroclasts developing asymmetric tails and stair steeping structures; $C$ and D) Mylonites with pertite porphyroclasts surrounded by fringes of polygonal metamorphic crystals with granoblastic texture (mantled porphyroclasts); E) Mylonite with stretched aegirine porphyroclasts surrounded by dark blue amphibole fringes (riebeckite); F) Detail of fig. 7E - Aegirine porphyroclasts involved by amphiboles. Abbreviations of the minerals: Px- Piroxene (Aegirine), Anf-Amphibole, Kf-Kfeldspar (Pertite). 


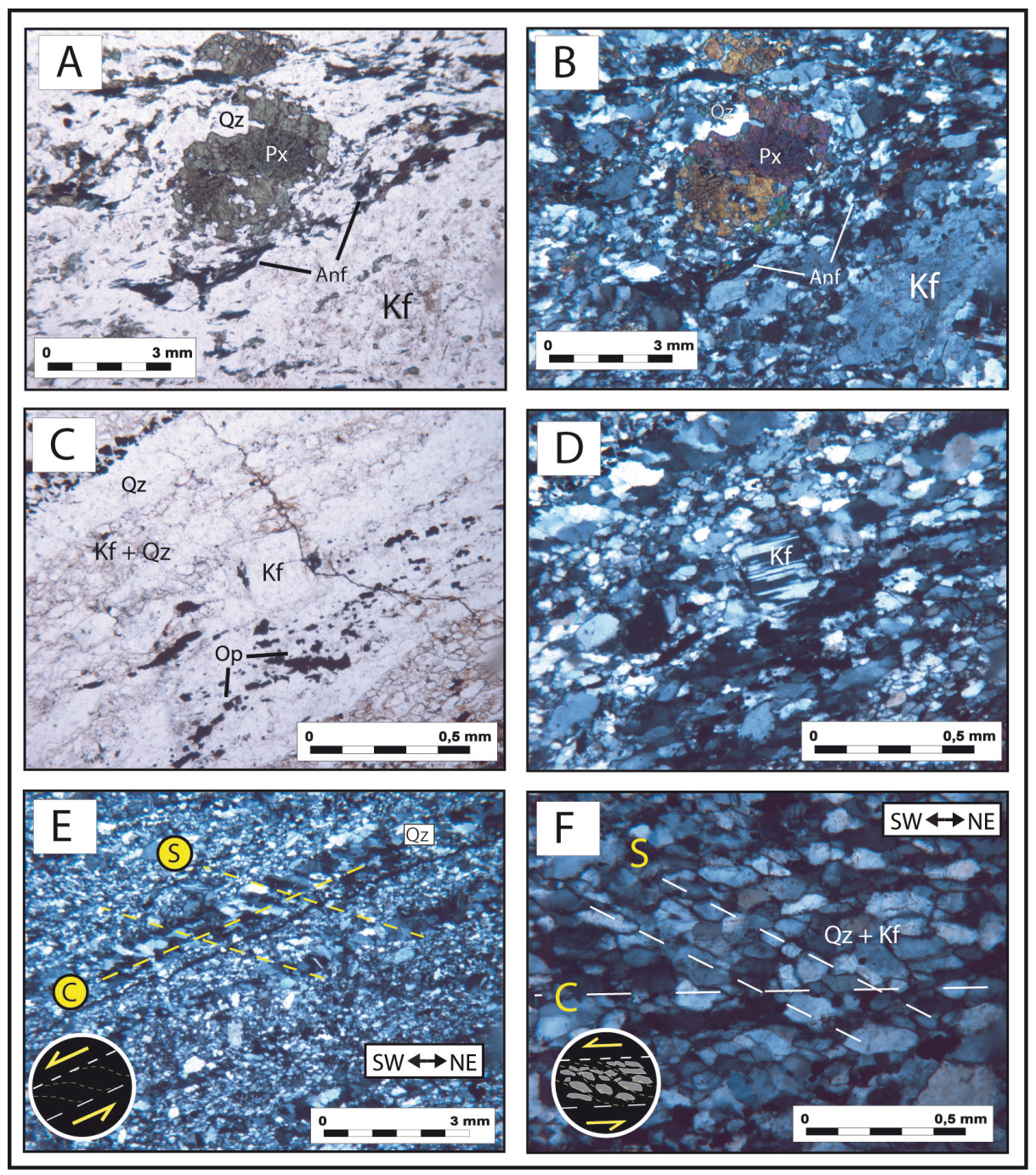

Figura 8. Fotomicrografias do MC. A e B) Milonito com porfiroclastos de aegirina estirados de até 3 mm (centro), envoltos por finas trilhas de anfibólio em textura nematoblástica; C e D) Ultramilonito com bandamento continuo definido por níveis ricos em quartzo e em K-feldspato; ao centro, porfiroclasto de K-feldspato; E) Ultramilonito com bandamento fino intercalando níveis ricos em quartzo alongados e níveis feldspáticos; nos níveis de quartzo observa-se uma foliação oblíqua (oblique fabric), definindo planos de cisalhamento S-C e movimento lateral esquerdo; F) Detalhe da matriz com textura granoblástica poligonal e a foliação oblíqua.

Figure 8. Photomicrographs of MC. A and B) Mylonite with stretched aegirine porphyroclasts with up to 3 mm diameter (center), involved by thin lenses of amphibole-rich nematoblastic texture; $C$ and D) Ultramylonite with regular banding defined by quartz and K-feldspar-rich levels; in the center, K-feldspar porphyroclast; E) Ultramilonite with thin banding defined by intercalation of quartz-rich and feldspar-rich levels; in the quartz-rich bands there is an oblique fabric defining the S-C shear planes and left lateral movement; F) Detail of the matrix with poligonal granoblastic texture and oblique fabric.

As microestruturas e texturas observadas permitem estimar os intervalos de temperaturas atingidas durante a deformação além de auxiliar, pelos indicadores cinemáticos, na investigação cinemática da deformação. Nas porções protomiloníticas os porfiroclastos de pertita estão parcialmente quebrados, com extinção ondulante e pouca recristalização nas bordas, quando comparadas aos termos miloníticos. Nos milonitos, o feldspato apresenta exsolução de albita em forma de manchas, com intensa recristalização gerando textura granoblástica poligonal, principalmente, das bordas para centro dos porfiroclastos ou por fraturas causadas pela própria deformação (Fig. 7C e 7D). Esse tipo de feição é classificada como textura de núcleo e manto (core e mantle textures) e sugere deformação milonítica de médio grau $\left(\sim 500^{\circ} \mathrm{C}\right)$ (Passchier \& Trouw, 1996; Trouw et al., 2010).

Os porfiroclastos de aegirina e titanita estão quebrados e estirados segundo a foliação milonítica por processos de cominuição e boudinagem, formando caudas de deformação assimétricas gerando indicadores cinemáticos do tipo sigma com movimentação de topo para NE (Fig. 7B e 7E). A aegirina está fortemente associada com anfibólio sódico de cor azul marinho escuro (riebeckita), possivelmente ligada a processos de hidratação do piroxênio durante o cisalhamento. 


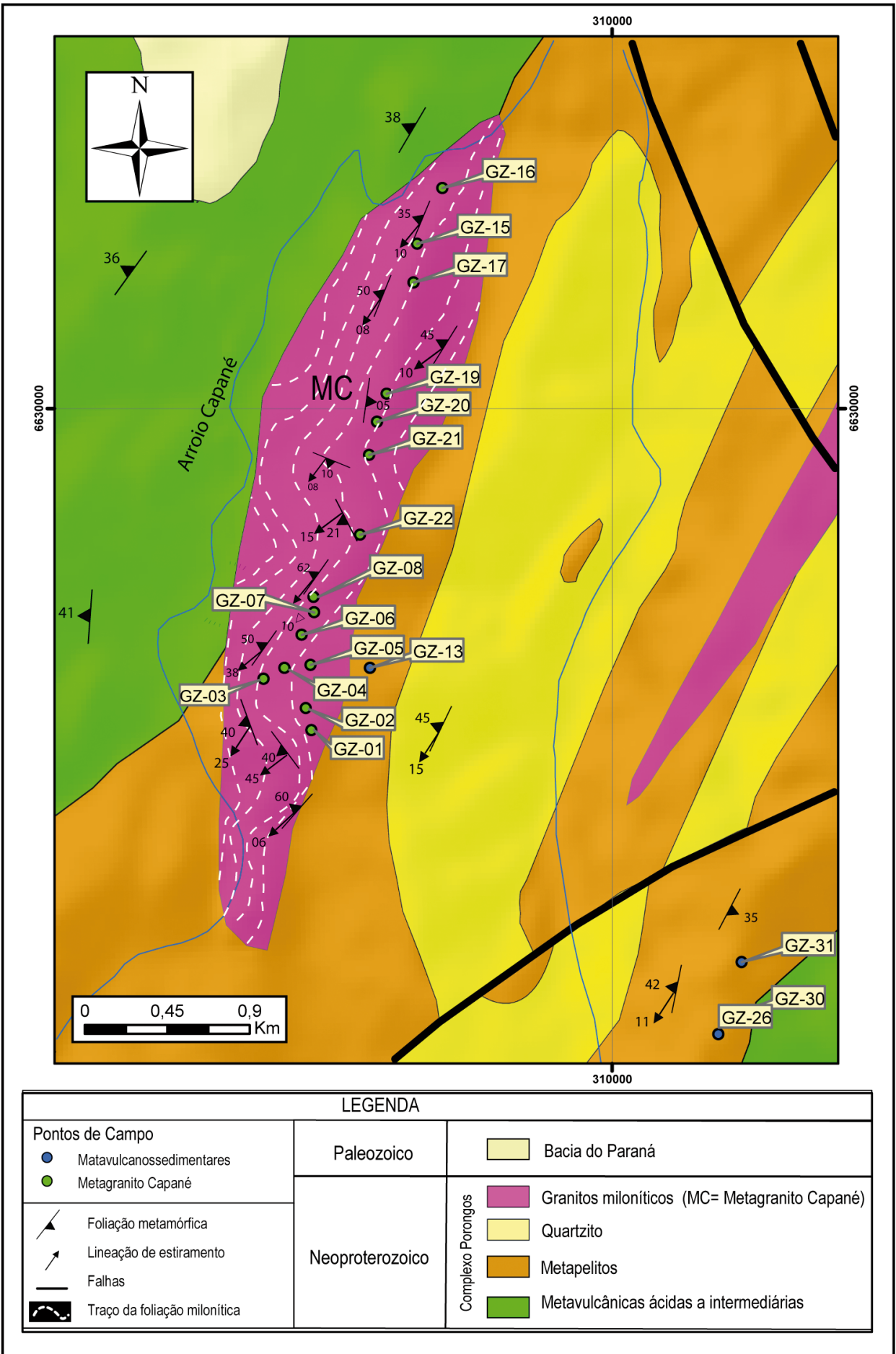

Figura 9. Mapa geológico do Metagranito Capané (MC)e suas encaixantes, com os pontos de campo e as principais estruturas. Figure 9. Geological map of Capané Metagranite (MC) and its host rocks, showing the location of the sampling sites and the main structures.

\subsection{Análise Estrutural}

A análise estrutural foi obtida a partir da integração entre os dados de campo e os dados petrográficos que permitiram reconhecer quatro fases deformacionais $\left(\mathrm{D}_{1}, \mathrm{D}_{2}, \mathrm{D}_{3}\right.$ e $\left.\mathrm{D}_{4}\right)$ e caracterizar o grau metamórfico e a intensidade da deformação que afetaram as unidades da Antiforme Capané.

A primeira fase deformacional $D_{1}$ está pre- servada nos metapelitos, quartzitos e mármores como uma xistosidade reliquiar $S_{1}$ que define dobras apertadas e isoclinais intrafoliais $\left(\mathrm{F}_{2}\right)$, de dimensões milimétricas a centimétricas, geradas no evento deformacional $\mathrm{D}_{2}$. A xistosidade $\mathrm{S}_{2}$ é definida por clivagem de crenulação com atitude média $\mathrm{N} 05^{\circ} \mathrm{E}$, mergulhando com variações de $30^{\circ}-50^{\circ}$ o para NW e SE devido ao dobramento durante a fase deformacional D3 (Fig. 10A). A xistosidade $\mathrm{S}_{2}$ foi gerada sob condições entre as fácies xisto ver- 
de inferior e anfibolito. A lineação de estiramento (Lx), associada à foliação $S_{2}$, tem caimento de baixo ângulo para NE e SW (Fig. 10B).

A orientação da foliação milonítica do MC $(\mathrm{Sm})$ apresenta uma atitude média $\mathrm{N} 27^{\circ} \mathrm{W}$ mergulhando $54^{\circ}$ para SW (N343/54SW), com variação de direção para N-S, chegando a mergulhos de até $10^{\circ}$ (Fig. 9 e 11A). A lineação de estiramento (Lx) tem uma direção média de S27W, com caimento em baixo ângulo $\left(\sim 10^{\circ}\right)$, muito similar à lineação de estiramento dos metassedimentos (Fig. 10A e B e $11 \mathrm{~A}$ e B). A relação da lineação de estiramento com a foliação milonítica é variada. Em zonas de alta deformação a Lx indica movimentação de caráter transcorrente, enquanto que em zonas de mais baixa deformação registram uma movimentação oblíqua de caráter compressivo (Fig. 11E).

Os estereogramas da foliação milonítica (Sm) do $\mathrm{MC}$ e da xistosidade $\mathrm{S}_{2}$ das encaixantes mostram que ambas estruturas estão deformadas e afeta-

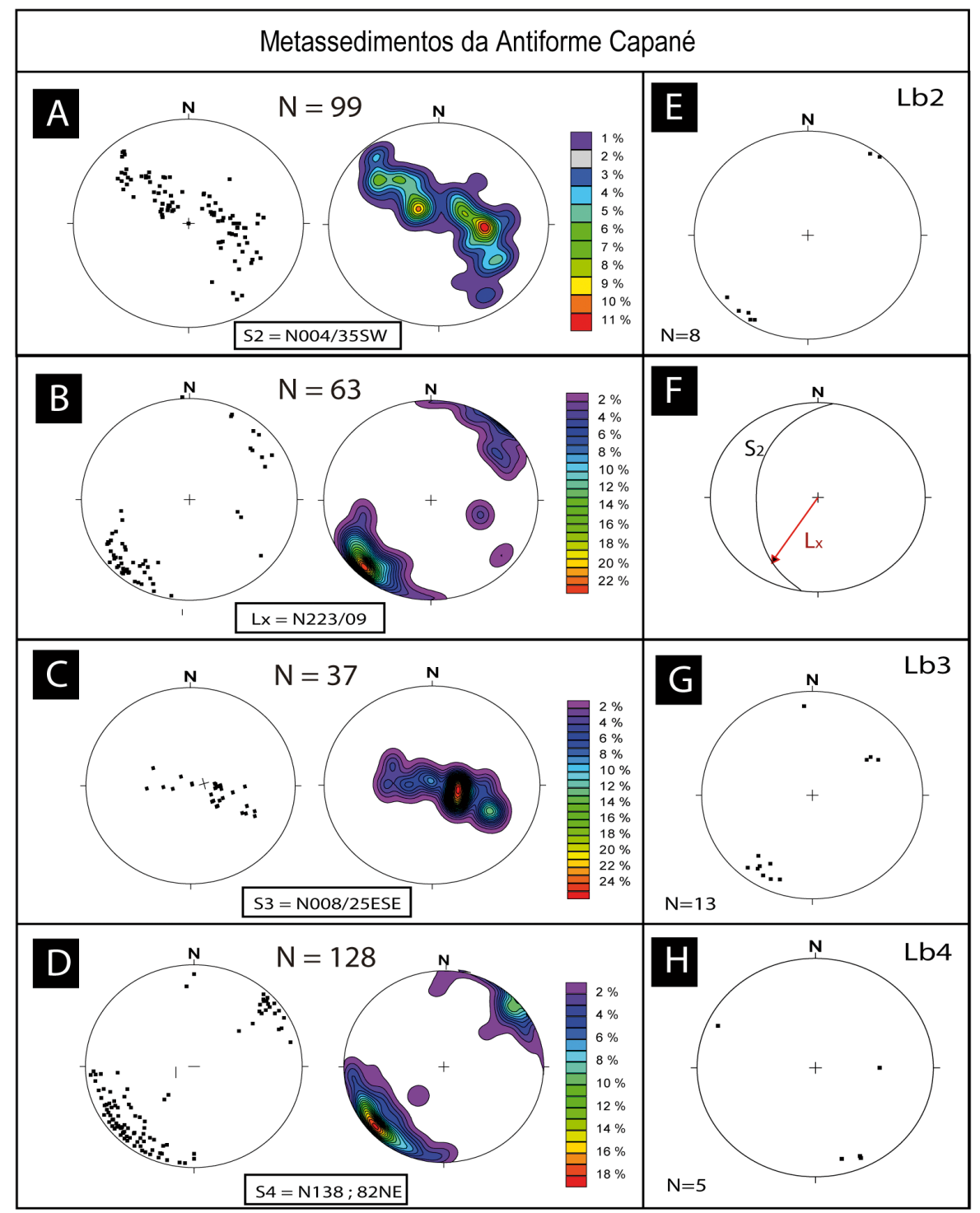

Figura 10. Estruturas planares e lineares do Complexo Porongos na Antiforme Capané representadas em rede equiárea de Schmit (hemisfério inferior). A) Projeção dos pólos do plano de foliação $S_{2}$ (foliação metamórfica $S_{1} / / S_{2}$, à esquerda, e diagrama de contorno para a distribuição de polos de planos à direita; B) Orientação da lineação de estiramento (Lx) (à esquerda) e diagrama de contorno para a distribuição das concentrações de linhas (à direita); C) Distribuição dos pólos dos planos da superfície-axial $S_{3}$ (à esquerda) e diagrama de contorno para a distribuição de pólos (à direita); D) Projeção dos pólos dos planos (à esquerda) e diagrama de contorno para a distribuição dos pólos dos planos da clivagem de fraturas $\mathrm{S}_{4}$; E) Orientação dos eixos $\mathrm{Lb}_{2}$ das dobras $\mathrm{F}_{2}$ em estereograma de linhas; F) Relação entre a moda da foliação $\mathrm{S}_{2}$ com a lineação de estiramento Lx; $\mathrm{G}$ e H) Orientação dos eixos $\mathrm{Lb}_{3}$ e $\mathrm{Lb}_{4}$ das dobras $\mathrm{F}_{3}$ e $\mathrm{F}_{4}$.

Figure 10. Planar and linear structures of Porongos Complex in the Capané Antiform ploted on the lower hemisphere. A) Projection of poles of metamorphic foliation planes $\left(S_{1} / / S_{2}\right)$ (on left hand side) and contour diagram on the right hand side; $B$ ) Orientation of stretching lineation ( $(\mathrm{Lx})$ on the left and contour diagram on the right; $C)$ Distribution of pole plane of axial surface $\left(S_{3}\right)$ on the left and contour diagram - on the right; D) Projection of poles planes (left) and contour diagrams (right) of spaced clivage S4; E) Orientation of $\mathrm{F}_{2}$ fold axis $\left(\mathrm{Lb}_{2}\right) ; \mathrm{F}$ ) Relationship between foliation $\left(\mathrm{S}_{2}\right)$ with stretching lineation $\mathrm{Lx}$; $\mathrm{G}$ and $\left.\mathrm{H}\right)$ Orientation of $\mathrm{F}_{3}$ and $F_{4}$ fold axis $\left(\mathrm{Lb}_{3}\right.$ and $\left.L b_{4}\right)$ respectively. 
das pelas dobras $F_{3}$, definindo uma guirlanda no estereograma da figura $10 \mathrm{~A}$ e $11 \mathrm{~A}$. Esta variação materializa o dobramento da xistosidade $\mathrm{S}_{2}$ e da foliação milonítlica, formando as dobras abertas a suaves da fase $\mathrm{D}_{3}$, com o desenvolvimento da clivagem de fratura $\mathrm{S}_{3}$ nas superfícies axiais das dobras $\mathrm{F}_{3}$ (Fig. 10C). Esta fase deformacional se desenvolveu em condições de deformação dúctil-rúptil e é responsável pela geração da Antiforme Capané.

Todas as unidades são afetadas por uma fase $\mathrm{D}_{4}$ de deformação mais tardia, marcada por dobras $\mathrm{F}_{4}$ suaves a abertas, com eixos orientados segundo a direção NW-SE (Fig. 13). Em campo, a superfície axial destas dobras está marcada por uma clivagem de fratura subvertical $\left(\mathrm{S}_{4}\right)$, com espaçamento centimétrico a decimétrico e direção média de $\mathrm{N} 42^{\circ} \mathrm{W}$ (Fig. 10D e 11C). A geração desta estrutura marca uma significativa mudança de direção no campo tensional e nas condições deformacionais de cará- ter mais rúptil em relação às fases anteriores.

As quatro fases de deformação descritas estão registradas nas rochas metavulcanossedimentares do Complexo Porongos, enquanto no Metagranito Capané, a foliação milonítica $(\mathrm{Sm})$ corresponde à xistosidade $\mathrm{S}_{2}$ dos metassedimentos. As fases $\mathrm{D}_{3} \mathrm{e}$ $\mathrm{D}_{4}$ estão marcadas no granito pelas clivagens de fratura $\mathrm{S}_{3}$ e $\mathrm{S}_{4}$. Pelas características das foliações miloníticas e suas relações com a lineação de estiramento, a zona de cisalhamento que afetou o MC tem uma disposição sigmoidal, gerando no granito uma intercalação métrica de zonas de mais alta e baixa deformação desenvolvendo locais com predomínio de cisalhamento puro e locais com predomínio de cisalhamento simples para acomodar a deformação

A disposição espacial destas estruturas está representada na seção geológica esquemática na figura 14.

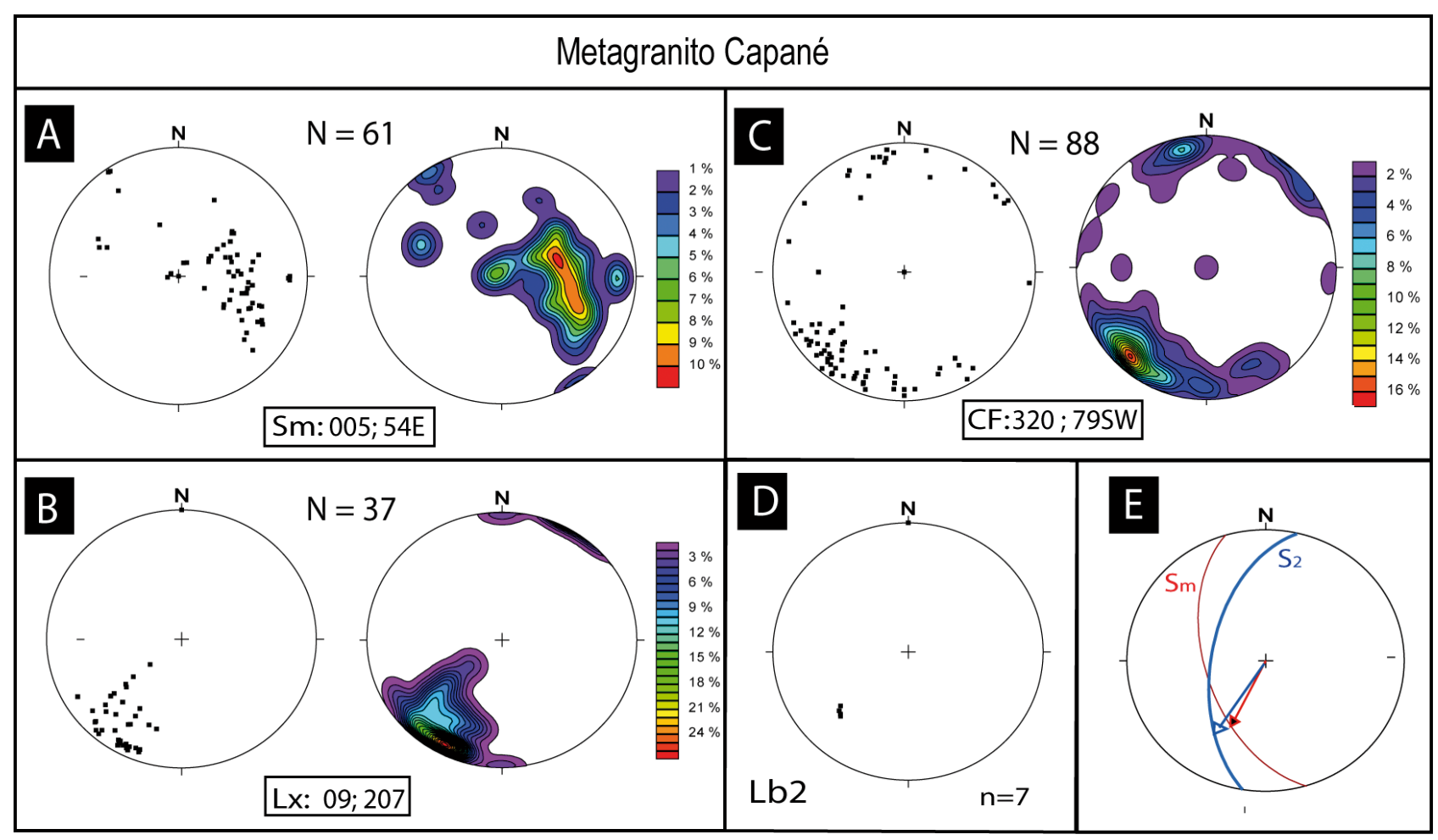

Figura 11. Estruturas planares e lineares do Metagranito Capané representadas em rede equiárea de Schmidt (hemisfério inferior). A) Projeção dos pólos dos planos da foliação milonítica Sm (à esquerda) e diagrama de contorno para a distribuição dos polos (à direita); B) Orientação da lineação de estiramento e diagrama de contorno para a distribuição das concentrações de

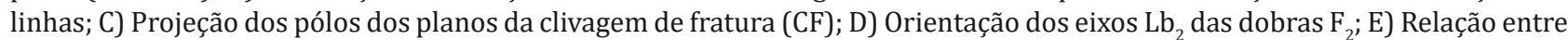
os planos de foliação milonítica $(\mathrm{Sm})$ e da xistosidade $\left(\mathrm{S}_{2}\right)$ com as respectivas lineações de estiramento (setas).

Figure 11. Planar and linear structures of the Capané Metagranite ploted on the lower hemisphere. A) Projection of poles of mylonitic foliation planes (Sm) (on left hand side) and contour diagram distribution (right hand side); B) Orientation of stretching lineation and contour diagram; $C$ ) Projection of poles of space clevage; D) Orientation of $F_{2}$ fold axes ( Lb $_{2}$ ); E) Relationship between mylonitic foliation planes (Sm) and metamorphic foliation $S_{2}$ with respective stretching lineations (arrows). 


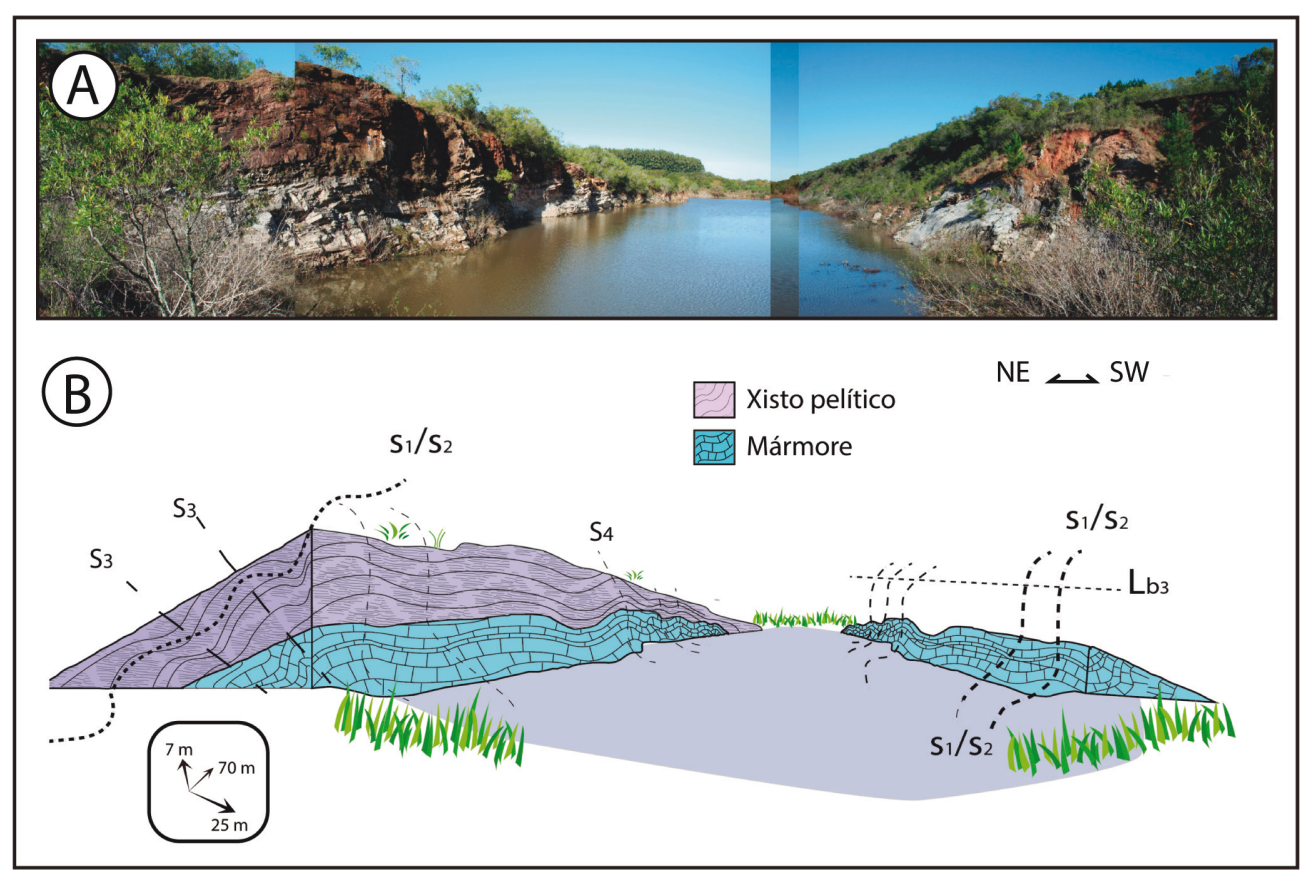

Figura 12. Croqui esquemático com a interpretação das estruturas apresentadas pelos metassedimentos do Complexo Porongos em antiga mina de mármore. A) Fotomosaico de cava de pedreira de mármore em contato com xistos pelíticos sotopostos; B) Croqui esquemático representando as feições estruturais. $S_{1} / / S_{2}$ : xistosidade; $S_{3}$ e $S_{4}$ : clivagem de fratura de superfície-axial; Lb: eixo de dobra.

Figure 12. Schematic sketch with the structural interpretation of Porongos Complex metasediments in an abandoned marble quarry. A) Photomosaic of quarry pit showing the contact between marbles and overlaying pelitic schists; B) Schematic sketch with the main structural features. $S_{1} / / S_{2}$ : schistosity; $S_{3}$ and $S_{4}$ : spaced cleavage; Lb: fold axis.
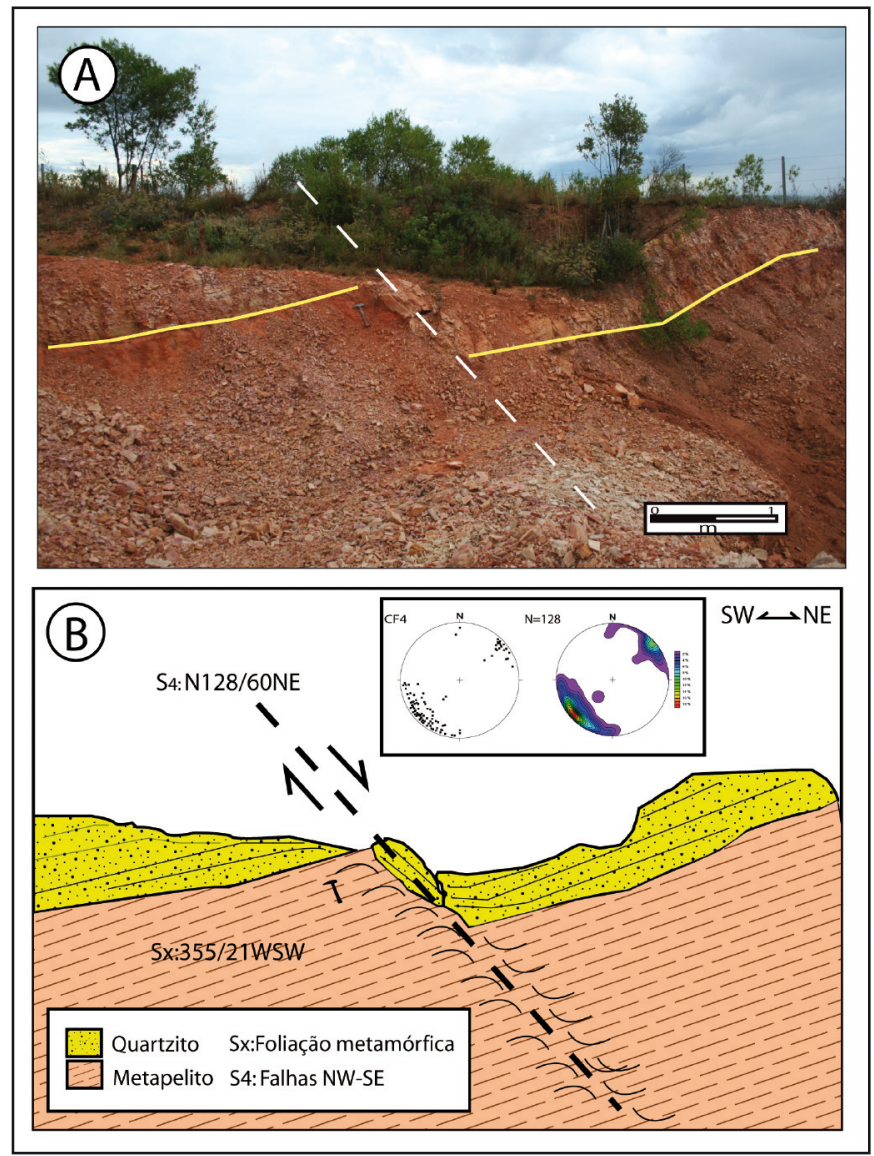

Figura 13. Feições estruturais de campo da fase deformacional $D_{4}$ A) Fotografia do ponto GZ-26; B) Croqui esquemático destacando falha normal de direção NW-SE com deslocamento dos níveis de quartzito e xisto pelítico relacionados à fase de deformação rúptil $\mathrm{D}_{4}$.

Figure 13. Structural field feature of deformational phase $D_{4}$. A) Picture of point GZ-26; B) Schematic sketching highlighting $N W$-SE-oriented normal fault with of quartzite and pelitic schists related to the ruptile D4 deformational phase. 




Figura 14. Seção geológica esquemática A-B do mapa geológico da figura 5 MC: Metagranito Capané. Figure 14. Schematic geological section A-B. See location in the Figure 5 MC: Metagranito Capané.

\section{Conclusões}

A análise estrutural integrada com a petrografia permitiu a descrição e caracterização petrográfica do $\mathrm{MC}$ e o reconhecimento de quatro fases deformacionais na área de estudo e a correlação destas fases com o a evolução geológica do MC.

As fases deformacionais $\mathrm{D}_{1}$ e $\mathrm{D}_{2}$ geraram as foliações metamórficas $S_{1}$ e $S_{2}$ de caráter dúctil com direção NE-SW. As fases $\mathrm{D}_{3}$ e $\mathrm{D}_{4}$ geraram estruturas de caráter rúptil-dúctil, sendo a primeira $\left(\mathrm{D}_{3}\right)$, a fase que produziu a Antiforme Capané e seus dobramentos suaves com eixos de direção NE. A fase $\mathrm{D}_{4}$ desenvolveu a clivagem de fratura $\mathrm{S}_{4}$, de direção NW e de caráter rúptil.

Essas informações indicam que as unidades que compõem a Antiforme Capané apresentam uma história deformacional complexa, sendo progressivamente deformadas por eventos inicialmente situados em níveis crustais mais profundos, gerando as foliações metamórficas $\mathrm{S}_{1}$ e $\mathrm{S}_{2}$ dos metassedimentos e em zonas de alta deformação e a foliação milonítica (Sm) que afetou o MC.

Não existem idades definidas para a deformação do Complexo Porongos, porém as idades de cristalização do MC ( $600 \mathrm{Ma})$ e metamórficas ( $\sim 560 \mathrm{Ma}$ ), juntamente com os dados isotópicos e geoquímicos das unidades da Antiforme Capané, sugerem uma evolução geológica mais jovem em relação as outras unidades do CP.
As análises petrográficas classificam o Metagranito Capané como um aegerina pertita granito milonítico com variações da intensidade da deformação registrada pelas variações texturais de protomiloníticas à ultramiloníticas. A relação genética entre a zona de cisalhamento dúctil que afeta o MC e as rochas encaixantes é de difícil abordagem em razão da falta de afloramentos para uma melhor correlação estrutural. Entretanto, o corpo granítico tem sua forma alongada concordante com a foliação $S_{2}$, que representa a principal xistosidade do complexo e que corresponde a foliação milonítica do granito.

As microestruturas, texturas e transformações mineralógicas identificadas no MC mostram que os termos miloníticos e ultramiloníticos apresentam microestruturas dúcteis geradas sob condições metamórficas de grau médio (500-650º $\mathrm{C}$ ). Essas condições são equivalentes, em parte, ao grau metamórfico registrado na foliação $S_{2}$ das rochas encaixantes. Contudo, a foliação milonítica do MC é concordante com a foliação metamórfica $\mathrm{S}_{2}$ e com a lineação de estiramento das rochas encaixantes. Portanto, a milonitização do MC ocorreu provavelmente durante a fase $\mathrm{D}_{2}$, em condições metamórficas de fácies anfibolito inferior a médio. 0 registro das estruturas dúcteis no MC sugere estar relacionado à fase $\mathrm{D}_{2}$, a qual se desenvolveu logo após a fase $\mathrm{D}_{1}$, talvez até de forma contínua, caracterizando a milonitização do MC como uma 
fase de deformação dúctil progressiva. As fases $\mathrm{D}_{3}$ e $\mathrm{D}_{4}$ afetam tanto os metassedimentos quanto o $\mathrm{MC}$, desenvolvendo as fases de dobramento $\mathrm{F}_{3}$ e $\mathrm{F}_{4}$ sobre as foliações metamórficas $S_{1}$ e $S_{2}$.

Os dados obtidos indicam que a evolução do Metagranito Capané esteve associada a uma tectônica oblíqua e de cinemática sinistral. Estas condições tectônicas estiveram associadas ao período pós-colisional do Cinturão Dom Feliciano, caracterizado por diversos episódios de compressão, extensão e cisalhamento transcorrente que imprimiram uma complexa trama de texturas e estruturas deformacionais, desde a colocação do Metagranito Capané até as múltiplas fases de deformação e metamorfismo subsequentes.

As idades obtidas para os metagranitos alcalinos intrusivos no Complexo Porongos indicam que o desenvolvimento das zonas de cisalhamento oblíquas que controlaram a ascensão e o posicionamento destas unidades plutônicas está associado ao período pós-colisional que afetou o Cinturão Dom Feliciano. Esta constatação é reforçada pelas idades metamórficas obtidas para a formação da xistosidade $\mathrm{S}_{2}$ e da foliação milonítica dos metagranitos. Estes dados também sugerem que a formação da Antiforme Capané e de outras estruturas regionais do Complexo Porongos é contemporânea à deposição dos sedimentos mais basais da Bacia do Camaquã ocorrida em níveis crustais mais superiores.

Agradecimentos. Ao Programa de Formação de Recursos Humanos em Geociências da PETROBRAS PRH PB 2015 pela bolsa de mestrado e apoio durante a pesquisa (Convênio no. 6000.0069471.11.4); aos revisores do trabalho e aos editores da revista Pesquisas em Geociências, especialmente o Prof. Dr. Paulo Alves de Souza, por seus comentários e sugestões que auxiliaram a aprimorar o presente manuscrito; ao CNPq pelo apoio através de bolsa de pesquisa.

\section{Referências}

Almeida, F.F.M. 1971. Geochronological division of the Precambrian of South America. Revista Brasileira de Geociências, 1: 13-21.

Babinski, M., Chemale Jr., F., Van Schmus, W.R., Hartmann, L.A. \& Silva, L.C. 1996. U-Pb and Sm-Nd geochronology of the Neoproterozoic granitic-gneissic Dom Feliciano belt, southern Brazil. Journal of South American Earth Sciences, 10(3-4): 263-274.

Basei M.A.S., Frimmel H.E., Nutman A.P. \& Preciozzi F. 2008. West Gondwana amalgamation based on detrital zircon ages from Neoproterozoic Ribeira and Dom Feliciano belts of SouthAmerica and comparison with coeval sequences from SW Africa. In: Pankhurst R.J., Trouw R.A.J., Brito Neves B.B. \& de
Wit M.J. (Eds.), West Gondwana, Pre-Cenozoic correlations across the South Atlantic region. Geological Society, London, Special Publication, 294: 239-256.

Bucher, K. \& Grapes, R. 2011. Petrogenesis of Metamorphic Rocks. Berlin, Springer-Verlag, 428p.

Camozzato, E. \& Marques, S.P.P. 1977. Geologia das Cabeceiras do Arroio Capané - Cachoeira do Sul/RS (Área VI). São Leopoldo, 127p. Trabalho de Conclusão de Graduação em Geologia, Universidade do Vale do Rio dos Sinos.

Camozzato, E., Lopes, R. C., Philipp, R. P., \& Klein, C. 2012. Geologia e Recursos Minerais da Folha Hulha Negra (SH.22-Y-C-I). Programa de Levantamentos geológicos básicos, CPRM, Porto Alegre, 164 p.

Camozzato E., Philipp R.P. \& Chemale Jr., F. 2013. Evolução Tectônica e Geocronologia U-Pb em zircão da terminação sul do Terreno Tijucas (RS, Brasil). In: VII CONGRESO URUGUAYO DE GEOLOGÍA, Resúmenes Extendidos, Montevideo, p. 7.

Chemale Jr., F. 2000. Evolução geológica do Escudo Sul-Rio-Grandense. In: Holz, M. \& De Ros, L.F. (Eds.), Geologia do Rio Grande do Sul. Porto Alegre, Editora da UFRGS, p. 13-52.

Chemale Jr., F., Gresse, P.G., Silva, L.C., Hartmann, L.A. \& F. Walraven. 1995. Tectonic evolution of the Brasiliano-Pan-African cycle in the southern Brazil and South Africa. In: SIMPÓSIO NACIONAL DE ESTUDOS TECTÔNICOS, 5, Boletim de Resumos Expandidos, SBG, Gramado, RS, p. 14.

Fernandes, L.A.D., Tommasi, A. \& Porscher, C.C. 1992. Deformation Patterns in the Southern Brazilian Branch of the Dom Feliciano Belt, a reappraisal. Journal of South American Earth Science, 5: 77-96.

Fernandes, L.A.D., Menegat R., Costa, A.F.U., Koester, E., Porcher, C.C., Tommasi, A., Kraemer, G., Ramgrab, G.E. \& Camozzato, E. 1995. Evolução Tectônica do Cinturão Dom Feliciano no Escudo Sul-rio-grandense: Parte II - uma contribuição a partir das assinaturas geofísicas. Revista Brasileira de Geociências, 25(4): 375-384.

Fragoso Cesar, A.R.S. 1980. O Cráton do Rio de La Plata e o Cinturão Dom Feliciano no Escudo Uruguaio-Sul Riograndense. In: CONGRESSO BRASILEIRO DE GEOLOGIA, 31, Anais... SBG, Camboriú, v. 5, p. 2879 2891.

Gollmann, K., Marques, J.C., Frantz, J.C. \& Chemale Jr., F. 2008. Geoquímica e Isotópos de Nd de Rochas Metavulcânicas da Antiforme Capané, Complexo Metamórfico Porongos, RS. Pesquisas em Geociências, 35(2): 83-95.

Gruber, L., Porcher, C.C., Lens, C., \& Fernandes, L.A.D. 2011. Proveniência dos metassedimentos das seqüências Arroio Areião, Cerro Cambará e Quartzo Milonitos no Complexo Metamórfico Porongos, Santana da Boa Vista, RS. Pesquisas em Geociências, 38(3): 205-223.

Hartmann, L.A. 1988. Geoquímica de Terras Raras e Geotermobarometria de Granulitos de Dom Pedrito e Luis Alves, no Extremo Sul do Brasil. Geochimica Brasiliensis, 2(1): 1-14.

Hartmann, L.A. \& Jost, H., 1980. Gnaisses alcalinos da 
Antiforme Capané. Acta Geologica Leopoldensia, 4: 13-26.

Hartmann, L.A., Philipp, R.P., Liu, D., Wan, Y., Wang, Y., Santos, J.O.S. \& Vasconcellos, M.A.Z. 2003. Paleoproterozoic magmatic provenance of detrital zircons, Porongos Complex Quartzites, souther Brazilian shield. International Gology Review, 46: 127-157.

Hartmann, L.A., Chemale Jr., F. \& Philipp, R.P. 2007. Evolução geotectônica do Rio Grande do Sul no Pré-Cambriano. In: Iannuzzi, R. \& Frantz, J.C. (Eds.). 50 Anos de Geologia: Instituto de Geociências. Contribuições. Porto Alegre, Editora Comunicação e Liberdade, p. 59-77.

Hartmann, L.A., Philipp, R.P., Santos, J.O.S. \& McNaughton, N.J. 2011. Time frame of 753-680 Ma juvenile accretion during the São Gabriel orogeny, southern Brazil. Gondwana Research, 19: 84-99.

Jost, H. 1981. Geology and Metallogeny of the Santana da Boa Vista region, South Brazil. Georgia, 208p. Tese de Doutorado, Universidade de Atenas.

Jost, H. \& Bitencourt, M.F. 1980. Estratigrafia e tectônica de uma fração da Faixa de Dobramentos Tijucas no Rio Grande do Sul. Acta Geologica Leopoldensia, 7: 27-59.

Mantovani, S.S.M., Hawkesworth, C.J. \& Basei, M.A.S. 1987. $\mathrm{Nd}$ and $\mathrm{Pb}$ isotope studies bearing on crustal evolution of Southeastern Brazil. Revista Brasileira de Geociências, 17(3): 263-268.

Marques, J.C., Jost, H., Roisenberg, A. \& Frantz, J.C. 1998a. Eventos ígneos da Suíte Metamórfica Porongos na área da Antiforme Capané, Cachoeira do Sul - RS. Revista Brasileira de Geociências, 28: 419-430.

Marques, J.C., Jost, H., Roisenberg, A. \& Frantz, J.C. 1998b. Rochas metassedimentares, geologia estrutural e metamorfismo da Suíte Metamórfica Porongos na área da Antiforme Capané, Cachoeira do Sul - RS. Revista Brasileira de Geociências, 28: 467-472.

Marques, J.C., Jost, H., Rosenberg, A., Frantz, J.C. \& Teixeira, R.S. 2003. Geologia e geoquímica das rochas ultramáficas da Antiforme Capané, Suíte Metamórfica Porongos, RS. Revista Brasileira de Geociências, 33(1): 83-94

Orlandi Fo, V., Pimentel, G. de B., Ramgrab, G.E. \& Camozzato, E. 2000. Folha Piratini (SH-22-Y-C-II), Estado do Rio Grande do Sul. CPRM: Brasília, Ed. 2009. Programa de Geologia do Brasil. CD. Texto Explicativo, 247p., mapa geológico e metalogenético/previsional 1:100.000.

Passchier, C.W. \& Trouw, R.A.J. 1996. Micro-tectonics. Berlin, Springer-Verlag, 365p.

Pertille J., Hartmann L.A., Philipp R.P., Petry T.S. Lana C.C. 2015. Origin of the Ediacaran Porongos Group, Dom Feliciano Belt, southern Brazilian Shield, with emphasis on whole rock and detrital zircon geochemistry and U-Pb, Lu-Hf isotopes. Journal of South American Earth Sciences, 64: 69-93.

Philipp, R.P. \& Machado, R. 2005. The Neoproterozoic to Cambrian Granitic Magmatism of Pelotas Batholith, Southern Brazil. Journal of South American Earth Sci-

Man 550 (nova submissão)

Editor: Paulo A. Souza. ence, 19: 461-478.

Philipp, R.P. \& H. Massonne, 2013. Peraluminous leucogranites of Cordilheira Suite: record of Neoproterozoic collision and generation of Pelotas Batholith, Dom Feliciano Belt, southern Brazil. Journal of South American Earth Sciences, 43: 8-24.

Philipp, R.P. \& Camozzato, E. 2009. A colocação do Batólito Pelotas e suas relações com o

metamorfismo regional orogênico no cinturão Dom Feliciano, RS. In: SIMPÓSIO NACIONAL DE ESTUDOS TCTÔNICOS, 12; INTERNATIONAL SYMPOSIUM OF TECTONIC STUDIES, 2009, Ouro Preto. Anais..., Ouro Preto, SBG, p. 112.

Philipp, R.P., Machado, R. \& Chemale Jr., F. 2007. A geração dos granitóides Neoproterozóicos do Batólito Pelotas: evidências dos isótopos de $\mathrm{Sr}$ e $\mathrm{Nd}$ e implicações para o crescimento continental da porção sul do Brasil. In: Iannuzzi, R. \& Frantz. J.C. (Ed.), 50 anos de Geologia: Instituto de Geociências. Contribuições. Porto Alegre, Comunicação e Identidade, p. 59-77.

Philipp, R.P., Lusa, M. \& Nardi, L.V.S. 2008. Geochemistry and petrology of dioritic, tonalitic and trondhjemitic gneisses from Encantadas Complex, Santana da Boa Vista, southernmost Brazil: a Paleoproterozoic continental-arc magmatism. Anais da Academia Brasileira de Ciências, 80: 735-748.

Remus, M.V.D., Faccini, U.F., Tedesco, M.A. \& Philipp, R.P. 1987. Evolução estrutural dos metamorfitos Porongos a sul do Rio Camaquã. Simpósio Sul-Brasileiro de Geologia, 3, Atas..., Curitiba, v. 1, p. 223-243.

Remus, M.V.D., Philipp, R.P., Faccini, U.F. \& Junges, S.L. 1990. Contribuição ao estudo geológico-estrutural dos Gnaisses Encantadas e das relações com as supracrustais Porongos na região de Santana da Boa Vista-RS. In: CONGRESSO BRASILEIRO DE GEOLOGIA, 36, Natal, Brasil, SBG, v. 2, p. 235-237.

Saalman, K., Hartmann L.A., Remus, M.V.D., Koester, E. \&. Conceição, R.V. 2005. Sm-Nd isotope geochemistry of metamorphic volcano-sedimentary successions in the São Gabriel Block, southernmost Brazil: evidence for the existence of juvenile Neoproterozoic oceanic crust to the east of the Rio de la Plata Craton. Precambrian Research, 136: 159-175.

Soliani Jr., E. 1986. Os dados geocronológicos do Escudo Sul-riograndense e suas implicações de ordem geotectônica. São Paulo, 425p. Tese de Doutorado, Instituto de Geociências, Universidade de São Paulo.

Trouw, R.A.J., Passchier, C.W. \& Wiersma, D.J. 2010. Atlas of Mylonites and related microstructures. Berlin, Springer-Verlag, 289p.

Zvirtes, G., Philipp, R.P., Chemale Jr., F., Camozzato, E. \& Guadagnin, F. 2013. Análise tectônica de granitos alcalinos no Rio Grande do Sul (RS, Brasil). In: CONGRESSO URUGUAIO DE GEOLOGIA. Montevidéo, Uruguai. Resumos Expandidos. 
